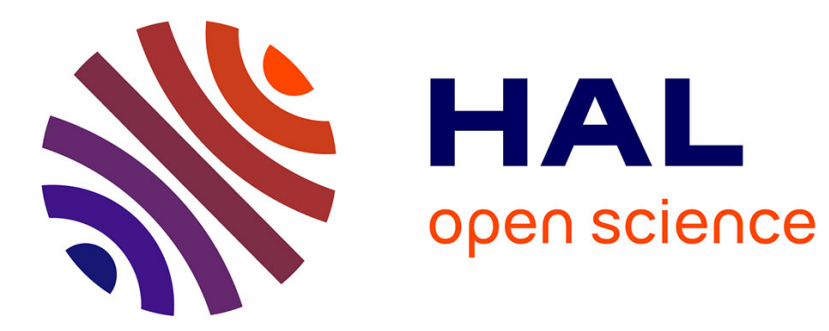

\title{
Memorial art as an Anthropological Object (Chin State of Burma)
}

François Robinne

\section{To cite this version:}

François Robinne. Memorial art as an Anthropological Object (Chin State of Burma). The Journal of Burma Studies, 2015, 19 (1), pp.199-241. 10.1353/jbs.2015.0001 . halshs-01866888

\section{HAL Id: halshs-01866888 \\ https://shs.hal.science/halshs-01866888}

Submitted on 5 Sep 2018

HAL is a multi-disciplinary open access archive for the deposit and dissemination of scientific research documents, whether they are published or not. The documents may come from teaching and research institutions in France or abroad, or from public or private research centers.
L'archive ouverte pluridisciplinaire HAL, est destinée au dépôt et à la diffusion de documents scientifiques de niveau recherche, publiés ou non, émanant des établissements d'enseignement et de recherche français ou étrangers, des laboratoires publics ou privés. 


\title{
The Journal of Burma Studies
}

\author{
Volume 19 Number 1 \\ June 2015
}

Northern Illinois University

Center for Burma Studies

Published by NUS Press

National University of Singapore

(C) 2015 Center for Burma Studies, Northern Illinois University ISSN: 1094-799X 


\section{Memorial Art as an Anthropological Object (Chin State of Burma)}

François Robinne

The Chin standing stones, which remain barely studied, highlight, due to the plurality of their appearances and various roles, the exceptional diversity - at once linguistic, cultural, religious, and political - that characterizes the social landscape of Chin State. Whether or not the patterns of those engraved scenes, which feature military victories, sacrificial rituals, and shamanic journeys, are accompanied by written texts, they are remarkable historical archives as they are often the only tangible sources, or in situ archival documents, for societies where an oral tradition still prevails. Art historians will try to assess the style and overall composition of the stones before attempting to decipher their artists. Moreover, anthropologists will more likely want to examine the relationship between the stones and the territory -in the context of clan segmentation and internationalizing migration dynamics.

The extreme social and linguistic diversity of Chin State, emphasized throughout the literature, has begun to overlap with an increasingly extended mobility. As seen with village and clan segmentations, urban migrations, Christian networks, and economic expatriation, even where mobility becomes structural to Chin subgroups, memorial art appears to be a major vector of social ties in ways that are both perennial and inconstant. Despite colonial and dictatorial violence that plunged Burma into civil war, social-and, therefore, memorial-change is expressed less in terms of rupture than 
of metamorphosis. At the same time as new leaders emerge and clan membership disappears behind denominational affiliations, ancestry has tended to turn more and more into a memory exercise taken over by Christianity.

\section{Memorial Space, Mobility, and Territorial Rooting}

\section{Context}

The steles, discussed in this study, are found scattered throughout the wider Chin territory, the Chinram that Lian H. Sakhong describes (2003: 7) as the original territory or "motherland" of the Chin. This motherland includes notably the territory of the $\mathrm{Zo}$, the generic name for the mountain people. Both the terms "Mizoram" and "Zomia" derive from this Zo appellation. Each represents regions that are the focus of competing nationalist claims, on both sides of the IndoBurmese border. The district of Tedim in the north is one of the main centers of this memorial space.

Access to Chin State is difficult, not only due to the steep terrain and improbable trails-Hakha is at an elevation of 1,850 meters-but also because as a crossroads of trans-frontier corridors bordering India and Burma, the central authorities have erected strict customs barriers across the area. After the 1962 Burmese coup d'état, access to what was then called the Chin Special Division became forbidden to anyone lacking Burmese citizenship. The last remaining Western missionaries were made to leave in 1966 (Bareigts 2003). Both Westerners and foreigners in general have since needed special authorization. While Burmese citizens are exempted, those not native to the region need to register upon arrival with the village chief under the authority of the Burmese government. It was at the invitation of an NGO called Groupe de Recherches et d'Échanges Technologiques (GRET) that I was given the opportunity to carry out research surveys in the area for two months, in July and October 2005. The goal of this study was to examine the socio-economic impact a decade of micro-finance activities ha and Robinne 2005).

After departing the pla win, as one plunges deep i Burma from India, steles $k$ nable roads destroyed ove. with precious woods. At fi: or white paint that often co themselves by their preser the multiplicity of these st assumption that they wer dhist Burma was already wood churches became vi: in the villages. The houses painted on wood or chalkı the assumption that thosi graves. After two more di exchange that took place the capital of Chin State, co "commemoration stones."

It is equally by chanc Saizang, near Tedim in th that the link between the $s$ alongside roads and a lî stones that were spotted apparent. My interest in stronger once discussions that an even larger numbr Later surveys showed tha same way in almost all thi

1 Hakha became the capital in 1 Constitution changed the name to Chin State. Chin State becam mountainous and border areas seven administrative divisions, ' and were located in the rice plai and in the Tenasserim. 
me as new leaders emerge rs behind denominational $\mathrm{o}$ turn more and more into Christianity.

\section{and}

udy, are found scattered sry, the Chinram that Lian $s$ the original territory or therland includes notably ic name for the mountain and "Zomia" derive from $s$ regions that are the focus in both sides of the Indoedim in the north is one al space.

not only due to the steep ikha is at an elevation of i crossroads of trans-fron3urma, the central authorriers across the area. After is to what was then called rbidden to anyone lacking ining Western missionarzigts 2003). Both Westernve since needed special iens are exempted, those ster upon arrival with the he Burmese government. alled Groupe de Recher(GRET) that I was given h surveys in the area for 35. The goal of this study ic impact a decade of micro-finance activities had had on the region (Danel-Fédou and Robinne 2005).

After departing the plains of the Irrawaddy and Chindwin, as one plunges deep into the mountain range separating Burma from India, steles began to appear along the interminable roads destroyed over the years by truck convoys laden with precious woods. At first inconspicuous, despite the blue or white paint that often covers them, they gradually imposed themselves by their presence all along the roads. It is in fact the multiplicity of these steles that made me doubt my initial assumption that they were used as boundary stones. Buddhist Burma was already far away when small brick and wood churches became visible by the sides of the roads and in the villages. The houses themselves often had white crosses painted on wood or chalked in above their doors, leading to the assumption that those steles must represent Christian graves. After two more days of travel, a short conversation exchange that took place shortly before arriving in Hakha, the capital of Chin State, confirmed that the steles were indeed "commemoration stones." 1

It is equally by chance, while entering the village of Saizang, near Tedim in the northernmost part of Chin State, that the link between the steles of smaller dimensions that lie alongside roads and a large group of imposing standing stones that were spotted near the village, became clearly apparent. My interest in those standing stones grew even stronger once discussions in the village highlighted the fact that an even larger number of them marked out the village. Later surveys showed that such steles were scattered in the same way in almost all the villages studied.

1 Hakha became the capital in 1974, when the promulgation of the second Constitution changed the name of the region from Chin Special Division to Chin State. Chin State became one of seven ethnic states located in the mountainous and border areas and was officially differentiated from the seven administrative divisions, which had dominant Burmese populations and were located in the rice plains of the valley and delta of the Irrawaddy and in the Tenasserim. 
Apart from a chapter devoted to them by F.K. Lehman (1963), the standing stones of the Chin have received almost no academic attention. This is ill-deserved because as the plurality of their appearances and different roles highlight, the steles point to the exceptional diversity - at once linguistic, cultural, religious, and political-that characterizes the social landscape of Chin State. In addition, those stones, which are found in a variety of sizes, are remarkable in that they are covered with engraved motifs of usually extremely intricate designs, which make them outstanding in both artistic, historical, and anthropological terms. The scenes depicted, which feature military exploits, sacrificial rituals, and shamanic voyages, represent for historians, regardless of whether or not they accompanied by written texts, a tangible primary source and a sort of in situ archival document of a context where the oral tradition still occasionally prevails. For art historians, this is an opportunity to try to identify amidst the stones' various styles, the different stone carving artists that attempted to depict elements of daily life and transmigration. Anthropologists, on the other hand, will see in the steles the successful preservation of links with ancestors, the clan memories associated with solidarity, courage, and fertility, as well as the different metamorphoses at work that lead us, through those stones, from "a totalizing savage mind" (Lévi-Strauss 1962: 791, 822) to a holistic frame of thought, in the Christian sense of the term (Roy 2008: 95; Bubandt and Otto 2010).

\section{The Plurality of Memorial Space}

The earliest monographs that were written in the wake of the first colonial expeditions of the late 19th century were dedicated to the distant, fetishist and belligerent tribes, referred to in contemporary terms as the "excluded areas." The "Pacification of Burma" gave rise to priceless works focusing on the "oral histories" of the war (Carey and Tuck [1896] 1976; Scott and Hardiman 1901; Crosthwaite 1912) and remarkable monographs (Hutton 1922; Parry 1932; Stevenson 1943). In fact, our knowledge of the populations living at the margins of the country was initially standing of the lowland administered by the centi studies are specifically $\mathrm{d} \epsilon$ stones, all of them mentic steles, thereby situating the sion, in the original soci served.

Because of the visual $\boldsymbol{c}$ they were at first thought toric times. In his analysis , area, Raphael Rousseleau accurately, and not withou felt a sense of "familiarit. of the mountainous outski reminiscent of the "megali feeling of ancientness was of the standing stones obse: writing, which came only $\mathrm{r} \epsilon$ the steles served as one of

Every element examined discussed here are of rele himself on elements of or memory of migration rout captions for Figures 8-12), Seipu - situated in the Indi borders Chin State - to the the realm of possibility, the stones dates them about $t v$ ing between three differer firmed this. Those three types of sources are:

- Engravings of people al both front and back of th sides if they are sufficier

- Collective oral tradition tification of the differer 
$d$ to them by F.K. Lehman Chin have received almost ll-deserved because as the d different roles highlight, diversity - at once linguiscal-that characterizes the In addition, those stones, zes, are remarkable in that notifs of usually extremely $n$ outstanding in both artisterms. The scenes depicted, sacrificial rituals, and sharians, regardless of whether en texts, a tangible primary val document of a context asionally prevails. For art o try to identify amidst the It stone carving artists that ily life and transmigration. $\mathrm{d}$, will see in the steles the th ancestors, the clan memurage, and fertility, as well work that lead us, through ivage mind" (Lévi-Strauss If thought, in the Christian dbandt and Otto 2010).

\section{Space}

written in the wake of the e 19th century were dediselligerent tribes, referred 'xcluded areas." The "Paciceless works focusing on rey and Tuck [1896] 1976; aite 1912) and remarkable 1932; Stevenson 1943). In ions living at the margins of the country was initially more thorough than our understanding of the lowland populations, who lived in areas administered by the central powers. While none of these studies are specifically devoted to studying the standing stones, all of them mention in greater or lesser detail the steles, thereby situating them, with varying amounts of precision, in the original societal and funerary contexts they served.

Because of the visual appearance of these "megaliths," they were at first thought to have originated during prehistoric times. In his analysis of the early British accounts of the area, Raphael Rousseleau (2008; forthcoming) points out accurately, and not without humor, how the queen's subjects felt a sense of "familiarity" as they discovered the steles of the mountainous outskirts of Assam, since they seemed reminiscent of the "megalithic groupings" of Scotland. This feeling of ancientness was reinforced by the fact that many of the standing stones observed in Chin State lacked traces of writing, which came only recently to the region, but for which the steles served as one of the first substrates.

Every element examined indicates that the standing stones discussed here are of relatively recent fabrication. Basing himself on elements of oral traditions and collective clan memory of migration routes, Lalthangliana (1975: 15-7 and captions for Figures 8-12) attributed the steles in the village Seipu - situated in the Indian state of Manipur border, which borders Chin State-to the 16th and 17th centuries. This is in the realm of possibility, though a closer examination of Chin stones dates them about two centuries later. Cross-referencing between three different types of sources has also confirmed this. Those three separate though complementary types of sources are:

- Engravings of people and animals, which usually cover both front and back of the steles and sometimes even their sides if they are sufficiently wide.

- Collective oral traditions, which have enabled the identification of the different clan chiefs represented on the 
steles and allowed the stones to be connected with one another.

- The colonial accounts, which have proven without a doubt that the heroes represented were contemporaries of that era.

Those combined sources have made clear the fact that the oldest steles ${ }^{2}$ were not anterior, with some exceptions, to the second half of the 19th century. The question remains as to whether such steles were manufactured in earlier times, but alas, an answer is not feasible. The most that can be said is that the standing stones discussed in this study were coeval with the very violent opposition of the local clan chiefs to the British colonial power from 1889 to 1890 (Crosthwaite 1912).

Colonial ethnography rapidly imposed the term "megalithic culture" as applied to the frontiers of continental (Fürer Haimendorf 1945) and dern 1959). However, because the standing stones discussed here are erected relatively recently-between the second half of the 19th and the beginning of the first half of the 20th century - and because they are studied throughout this article with an anthropological lens that discusses the ideas of mobility and territory, and also because they reference an ancestral memory exercise, I prefer to use the concept of "memorial space" over that of a "megalithic culture."

This memorial space is plural. Due to the combined effect of colonization and then independence; of Christianity and conversion dynamics; of the end of "traditional" political structures; and of years of civil war against the central Indian and Burmese governments, the acceleration of committed social change throughout a century does not always clarify the purpose of the steles. This process of cultural oblivion,

2 A similar conclusion was developed by A. Ziegler and A. Viaro (1999: 74) about Nias: "[...] the visible stone monuments should not be considered as part of archeology, but as part of history, and sometimes even of contemporary history given the alteration rate, we estimate the age of the oldest ones to be a hundred and fifty or two hundred years at most." which was initially encourag erased an entire and essentic

The varying structure and numerous possible ritual an whether or not they have res within the walls of a house o situated near a square or alo] light the range of possibly $\mathrm{d}$ : tification of certain abandon likely to remain shrouded ir

This is particularly true stones hanging a few centir entrance of the village of Lar heavy steles hidden in vegeta The latter are in fact so thick engraved on their edges with and some human heads, w] sculpted on them (Figures 1 are sometimes erected at th are in the same enclosures as attests to this practice (1981 was observed in 2005 in the explained to us that this was the domestic graves to be $\mathrm{n}$ In the historic village of $\mathrm{Ta}$ below Falam, two tombs star commemorating clan chiel the British. The tombs are surrounded by several eng grouped together in the squ. layer of blue paint applied whose faces are depicted or are identical in all respects $t$ roads in the region.

Funeral rituals do not al tombs or steles. In the regic part of Chin State, the bones terracotta urns (though the 
i to be connected with one

ave proven without a doubt were contemporaries of

made clear the fact that the rith some exceptions, to the The question remains as to tctured in earlier times, but he most that can be said is $d$ in this study were coeval if the local clan chiefs to the to 1890 (Crosthwaite 1912). imposed the term "megaintiers of continental (Fürer Southeast Asia (Heine-Gel: standing stones discussed $r$-between the second half $f$ the first half of the 20th died throughout this article liscusses the ideas of mobilthey reference an ancestral the concept of "memorial zulture."

Jue to the combined effect dence; of Christianity and I of "traditional" political $r$ against the central Indian acceleration of committed ry does not always clarify ocess of cultural oblivion,

$r$ A. Ziegler and A. Viaro (1999: Iments should not be considered ry, and sometimes even of conite, we estimate the age of the vo hundred years at most." which was initially encouraged by the missionaries, has now erased an entire and essential part of the collective memory.

The varying structure and size of the standing stones; their numerous possible ritual and symbolic functions, as well as whether or not they have remained in their original location within the walls of a house or a village; or whether they were situated near a square or along lines of communication highlight the range of possibly diverse answers. In fact, the identification of certain abandoned sites is an uncertain process, likely to remain shrouded in mystery.

This is particularly true of the grouping of small sharp stones hanging a few centimeters above the ground at the entrance of the village of Lamzang and is also the case for the heavy steles hidden in vegetation below the village of Sunthla. The latter are in fact so thick that they have elaborate patterns engraved on their edges with images of waves, fishes, gazelles, and some human heads, while their main sides have faces sculpted on them (Figures 14 to 16). In the south, the steles are sometimes erected at the foot of tombs, some of which are in the same enclosures as the houses. Research by Bareigts attests to this practice (1981) in the village of Hniaring and was observed in 2005 in the nearby village of Surkhua. It was explained to us that this was due to regulations, which forced the domestic graves to be moved to the Christian cemetery. In the historic village of Tashon farther north, a few miles below Falam, two tombs stand on the edge of a public square, commemorating clan chiefs known for having opposed the British. The tombs are shaped like pyramids and are surrounded by several engraved steles. Those stones were grouped together in the square and covered by a bad-quality layer of blue paint applied by descendants of the leaders whose faces are depicted on the engraved steles. The stones are identical in all respects to the ones that can be seen along roads in the region.

Funeral rituals do not always lead to the construction of tombs or steles. In the region of Tedim at the northernmost part of Chin State, the bones used to be deposited in funerary terracotta urns (though the dates from when this practice 
started and ended remain in question). One site full of such urns was found in the village of Mualbem, but systematic excavations are still needed. In the region of Falam, altars dedicated to the spirits are erected side-by-side wooden anthropomorphic sculptures. Those sculptures represent women and infants that died in childbirth. ${ }^{3}$ Offerings are sometimes left for their souls at the altars or placed on paths near cultivated plots, as a sign of fertility. These wooden sculptures sometimes stand aligned with steles, as they are often erected side by side on resting platforms that are close to communication lines (Figures 17 to 19). Some stones are engraved while others are not. Some steles are similarly placed in the villages, while some are put at their entrances, whereas others border fields or are aligned with caravan routes.

By necessity, once I confronted the great typological diversity of the region, the abandonment of shamanic rituals in the wake of Christianity, and the overall restructuring of social and political structures, my study became focused on one particular type of stele. Faced with the impossibility of establishing a comprehensive understanding of the memorial space in all its diversity, what finally stood out as a constraint also became a choice by forcing me to avoid what would have otherwise been a typological exercise: possibly relevant as an essentialist approach but leading to an impasse in sociological terms. Moreover, this choice proved fruitful when it became clear that the stones studied-erected to honor clan ancestors-were the ones that elicited the most comments in interviews with locals. In addition, I learned that the steles were preserved and regularly beautified by clan descendants who had long exiled themselves to the cities, but who would come back to their homeland as one going on a pilgrimage. And, while many of these steles are rundown, abandoned to

3 Unlike in the Indonesian Nias Island, where wooden poles are associated with the living, those in Chin State appear to be associated with the deceased, and in some cases, with the malemort (Ziegler andViaro 199: 70). the weather and the elem broken in pieces along rc material, they also can $\mathrm{dr}_{i}$ of a past still so close to painted to showcase unic ones that are sometimes ta] their native town.

Despite the diversity o cussed in this study are complementary themes: a the dead, and the continui territory of origin. They $\bar{c}$ independently of the woc other sacrificial offerings erection, and of being loci

\section{Mobility and Territo}

With her very rigorous ars of Upper Laos, Madeleine the first to highlight, usi positioning of "menhirs"' a this in her study and doe: of her analysis. However, State the steles are situate. most are located along car clearings. This is particula the steles stand on a pror as to allow passersby to taking a halt. This is simile and Tedim, where-with promontories-the steles and roads (Figure 1 ).

However, I argue tha stones along communicati focus of my analysis and the role played by the ste. tioning makes sense at $d$ 
stion). One site full of such f Mualbem, but systematic the region of Falam, altars zcted side-by-side wooden hose sculptures represent $\rightarrow$ childbirth. ${ }^{3}$ Offerings are he altars or placed on paths of fertility. These wooden red with steles, as they are ing platforms that are close 17 to 19). Some stones are Some steles are similarly e are put at their entrances, are aligned with caravan

the great typological divernt of shamanic rituals in the zrall restructuring of social ly became focused on one $x$ the impossibility of estabstanding of the memorial lly stood out as a constraint $\geq$ to avoid what would have ise: possibly relevant as an to an impasse in sociologi: proved fruitful when it ied-erected to honor clan ited the most comments in $n$, I learned that the steles itified by clan descendants , the cities, but who would ne going on a pilgrimage. :e rundown, abandoned to

tere wooden poles are associated sear to be associated with the mort (Ziegler andViaro 199: 70). the weather and the elements, submerged by vegetation, or broken in pieces along roads or even used as construction material, they also can draw tears of emotion as the symbol of a past still so close to us. It is those very stones that are painted to showcase unique designs and they are also the ones that are sometimes taken away by villagers when leaving their native town.

Despite the diversity of their appearances, the steles discussed in this study are linked to the same common and complementary themes: ancestrality, the commemoration of the dead, and the continuing attachments of migrants to their territory of origin. They also are alike in having been built independently of the wood sculptures, of not receiving any other sacrificial offerings than the ones made during their erection, and of being located near communication routes.

\section{Mobility and Territorial Rooting}

With her very rigorous archaeological study of the megaliths of Upper Laos, Madeleine Colani (1935: Figures 16 to 22) was the first to highlight, using supporting maps, the peculiar positioning of "menhirs"' along roads. She does not go beyond this in her study and does not make it a significant element of her analysis. However, regardless of which part of Chin State the steles are situated or their morphological diversity, most are located along caravan routes or old trails leading to clearings. This is particularly true in the area of Hakha where the steles stand on a promontory of dry stone, arranged so as to allow passersby to deposit heavy baskets on it while taking a halt. This is similarly the case in the regions of Falam and Tedim, where-without being systematically built on promontories - the steles are invariably located along trails and roads (Figure 1 ).

However, I argue that the positioning of the standing stones along communication lines is crucial and I make it the focus of my analysis and definition, in sociological terms, of the role played by the steles. This very marked spatial positioning makes sense at different levels. Both the territorial 


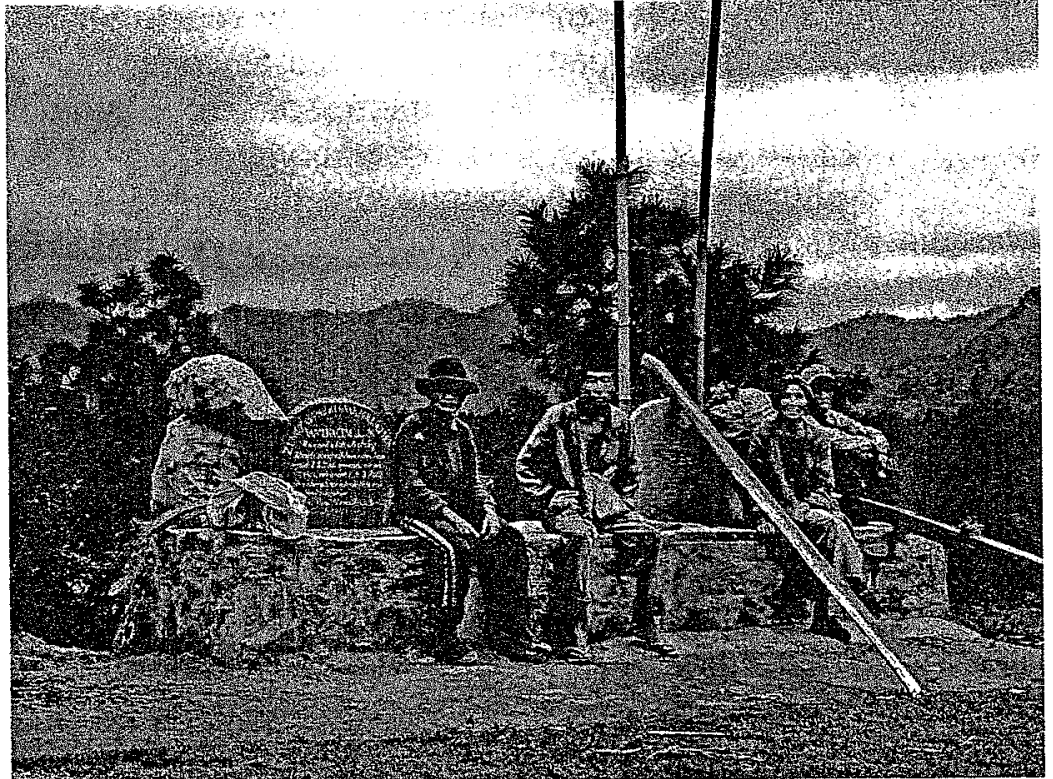

Figure 1 Triptych steles on promontories along a road near Hakha.

rooting of clan chiefs and the extent of their spheres of influence, as well as the recognition of the motherland as one of seven ethnic states (Chin) within a nation-state (the Union of Myanmar) turn these standing stones into signifiers of unbreakable territorial links.

F.K. Lehman (1963: 186-94) is correct, in a chapter entitled "The Memorial Concept of the Person: The Cult of Prosperity," to develop the idea of a duty of remembrance which shapes Chin societies' complex relationship to their land. Significantly, the Zomi terminology is well aware of this and in Saizang in the region of Tedim, the steles are called mual suang, literally translated as "mountain and stone."

The link to the territory may be horizontal in the case of tributes to those who have left the homeland, because of

4 They are called ling donh, "pierre dressée", in the regions of Hakha and Falam, an appellation which originated the names of several villages (Lok Lung, Lung Cawi). growing village mobility, , economic, political, or reli ducted in 2005 showed $\epsilon$ India-toward neighborin Madras but also to Malaysi; 64-9). The link to the territc rendered to fallen heroes believed, the prosperity of , symbolized by showing $t]$ phant during the transmig will show - is a recurring a] stones.

Everything in the social arrangements of populatic return of the deceased to th tation generated by the co inheritance of lands and $p$ and its corollary for its eld the trans-border caravan $]$ take place along the Indo numerous expatriations $\mathrm{W}$ returning, is decided by $\mathrm{m}$ term, and estrangement fro remains the structuring eler migration dynamics. The : cally commemorate this mi

This rooting to the hom many political, social and $r$ groups have endured. This have been progressively $\mathrm{mc}$ ized, and which are thems phosis. The memorial spar few remaining continuing should therefore be interpr which has occurred across it cannot be understood $w$ pearance of chiefdoms, the for independence, and the 


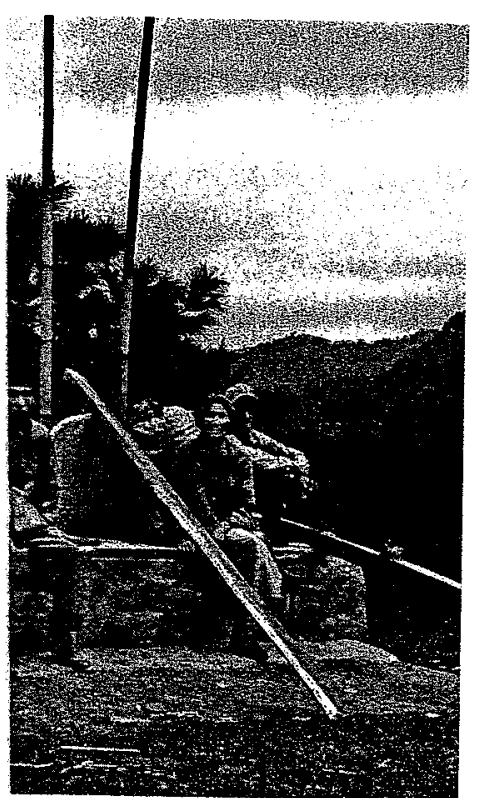

es along a road near Hakha.

it of their spheres of influthe motherland as one of nation-state (the Union of stones into signifiers of

irrect, in a chapter entitled 'son: The Cult of Prosper$y$ of remembrance which tionship to their land. Sigwell aware of this and in he steles are called mual tain and stone." ${ }^{\prime 4}$

horizontal in the case of ie homeland, because of

", in the regions of Hakha and names of several villages (Lok growing village mobility, clan segmentation, or, nowadays, economic, political, or religious expatriation. Surveys conducted in 2005 showed exponential migration growth to India - toward neighboring Mizoram - as well as to Delhi or Madras but also to Malaysia (Danel-Fédou and Robinne 2007: 64-9). The link to the territory is vertical in the case of tributes rendered to fallen heroes and ancestors on whom, it was believed, the prosperity of clan and village depended. This is symbolized by showing the deceased standing on an elephant during the transmigration trip-which, as the study will show -is a recurring artistic theme represented upon the stones.

Everything in the social, political, religious, or economic arrangements of populations in Chin State, regarding the return of the deceased to the ancestral land; the clan segmentation generated by the concept of ultimogeniture-that is, inheritance of lands and properties by the younger childand its corollary for its elders to conquer new territories; or the trans-border caravan networks and seasonal jobs that take place along the Indo-Burmese border, as well as the numerous expatriations which occur with no real hope of returning, is decided by mobility, in the wider sense of the term, and estrangement from the homeland. And yet the land remains the structuring element of those migration and transmigration dynamics. The standing stones exist to symbolically commemorate this modus operandi.

This rooting to the homeland is not fixed. It traverses the many political, social and religious upheavals that Chin subgroups have endured. This is seen through the steles, which have been progressively moved, painted over, and Christianized, and which are themselves imbued with this metamorphosis. The memorial space delineates in itself one of the few remaining continuing links to the Chin settlements and should therefore be interpreted in light of the social change which has occurred across the last decades. In other words, it cannot be understood without also examining the disappearance of chiefdoms, the yoke of colonialism, the struggle for independence, and the emergence of millenarian move- 
ments and Christian proselytizing. These aligned with some 50 years of civil war against the Burmese central government and the internationalization of migration dynamics.

Whether they are consubstantial with clan segmentation, voluntary or forced, with or without a return - on a seasonal or a long-term timeframe-migration dynamics push increasingly away from the original homeland, which is recalled through memorial art. To paraphrase Graeber's 1997 account of the Merina tombs, the standing stones of the Chin are, as shamanistic megaliths or as Christianized brick structures, "the ultimate link between people and places, the rooting of identity groups."

My analysis therefore considers the Chin standing stones to be an especially strong social operator, given that the dynamics of social change and mobility are consubstantial with identity formations and their social metamorphoses. To demonstrate this, the following study will successively discuss the tripartite morphology of standing stones; the genealogical links and clan segmentation that are evidenced by the steles; and the resilience and metamorphoses to which memory is subjected-in precis, a sense of memory in motion.

\section{Triptychs and Monoliths}

\section{A Similar Tripartite Structure}

The monolith stele MB01 (Figure 2), located on a side of the main road from Saizang to Mualbem, displays clearly a tripartite structure. Its upper third features a hunting scene showing two buffaloes surrounded by harder-to-identify animals; at its center, there is an image of the deceased, surrounded by his family, on an elephant; and a lower part, showing clan members drinking and dancing around animals that have been sacrificed in a commemoration celebration of the deceased. The latter also includes the erection of this stele. The geographical spread of such stones, which are of all sizes and shapes, is concentrated in the districts of Tedim and

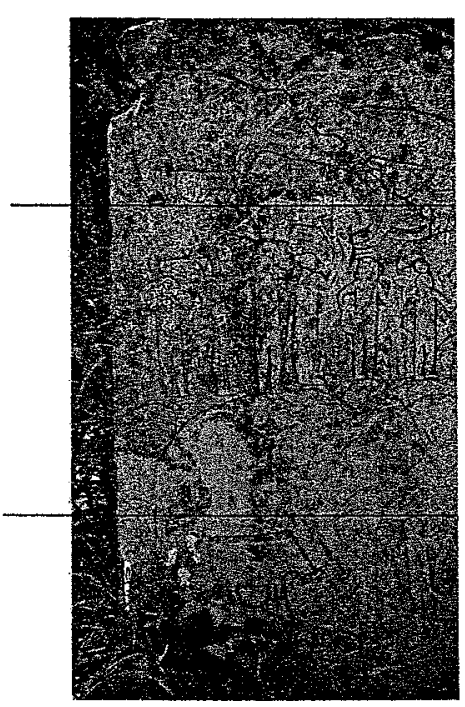

Figure 2 Stele monolithic MBO: Mualbem, commemorating the Sukte clan.

Tonzang in the northern $\mathrm{F}$ central region of Falam.

In Falam, as in Hakha fa of three side-by-side steles 01 (Figure 3)-situated at connects Falam to Taishon an incredible bestiary tha water buffalo, birds, mithan of Southeast Asia, Bibos fro

The tripartite structure one stele to another. As suc ceremony that led to the disappears along with the burial. This is the case with which allows a glimpse of a ground that depicts villag steles show two families, e 
g. These aligned with some urmese central government igration dynamics.

ial with clan segmentation, out a return - on a seasonal tion dynamics push increasmeland, which is recalled rase Graeber's 1997 account $\mathrm{g}$ stones of the Chin are, as istianized brick structures, 2 and places, the rooting of

s the Chin standing stones 1 operator, given that the nobility are consubstantial : social metamorphoses. To ; study will successively $y$ of standing stones; the gmentation that are evilience and metamorphoses i precis, a sense of memory

\section{ure}

2), located on a side of the sem, displays clearly a trifeatures a hunting scene led by harder-to-identify nage of the deceased, sursphant; and a lower part, id dancing around animals nemoration celebration of es the erection of this stele. ones; which are of all sizes le districts of Tedim and

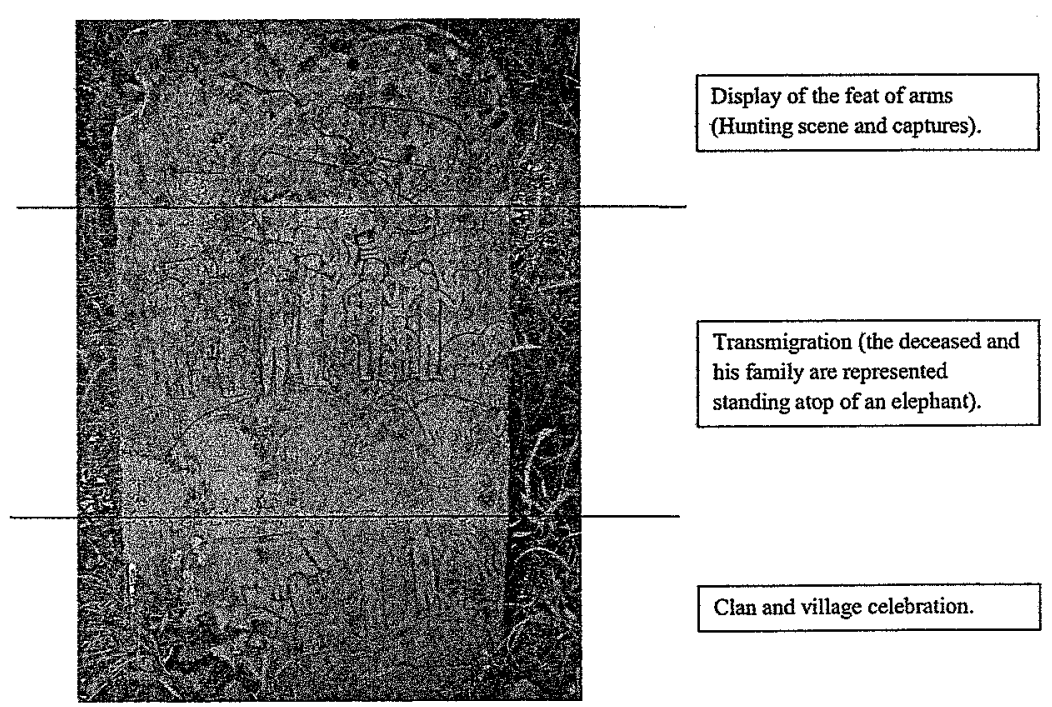

Figure 2 Stele monolithic MB01 (H.1.20 $\mathrm{m} \times 0.60 \mathrm{~m})$, at the entrance of Mualbem, commemorating the chief Thang Za Liang (+1936) of the Sukte clan.

Tonzang in the northern part of Chin State, but also in the central region of Falam.

In Falam, as in Hakha farther south, stele triptych consist of three side-by-side steles. The central standing stone TSH 01 (Figure 3)-situated at the edges of the steep path that connects Falam to Taishon-is decorated in its entirety with an incredible bestiary that interweaves tigers, bears, deer, water buffalo, birds, mithan (also known as gaur or gayal, ox of Southeast Asia, Bibos frontalis), and other animals.

The tripartite structure is more or less pronounced from one stele to another. As such, the lower part that portrays the ceremony that led to the erection of the stone sometimes disappears along with the part of the stone intended for burial. This is the case with the base of stele SZ02 (Figure 23), which allows a glimpse of a much larger frieze buried underground that depicts villagers drinking and dancing. Other steles show two families, each standing upon an elephant, a 


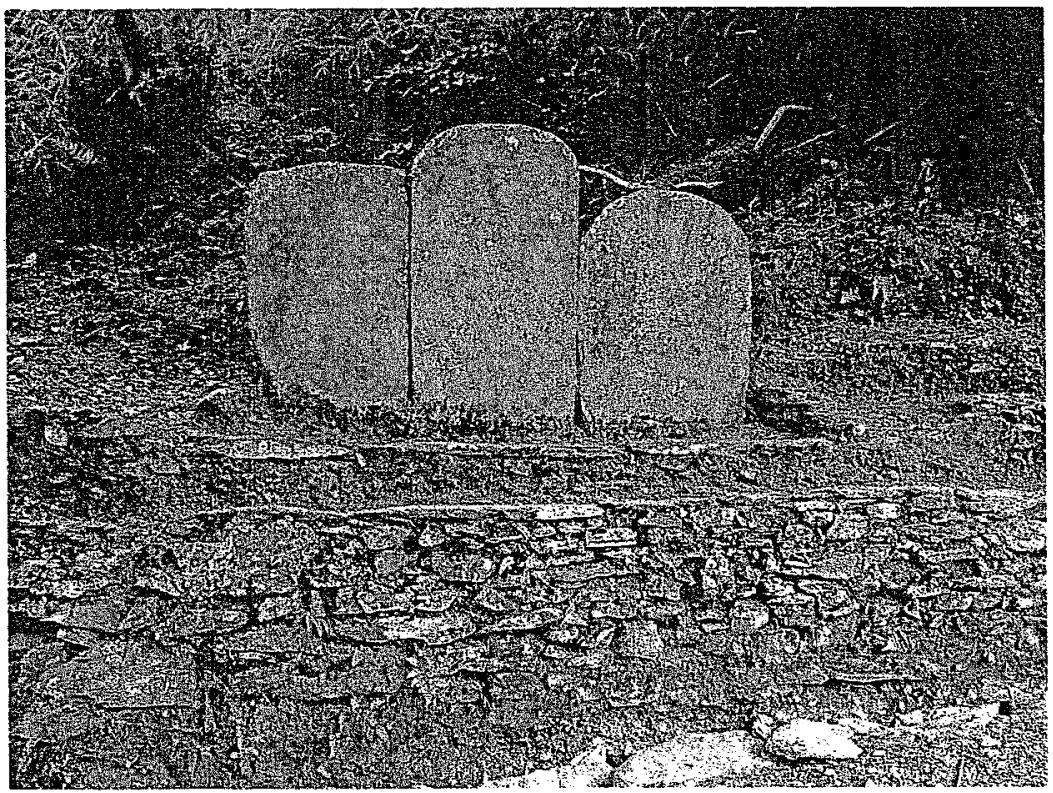

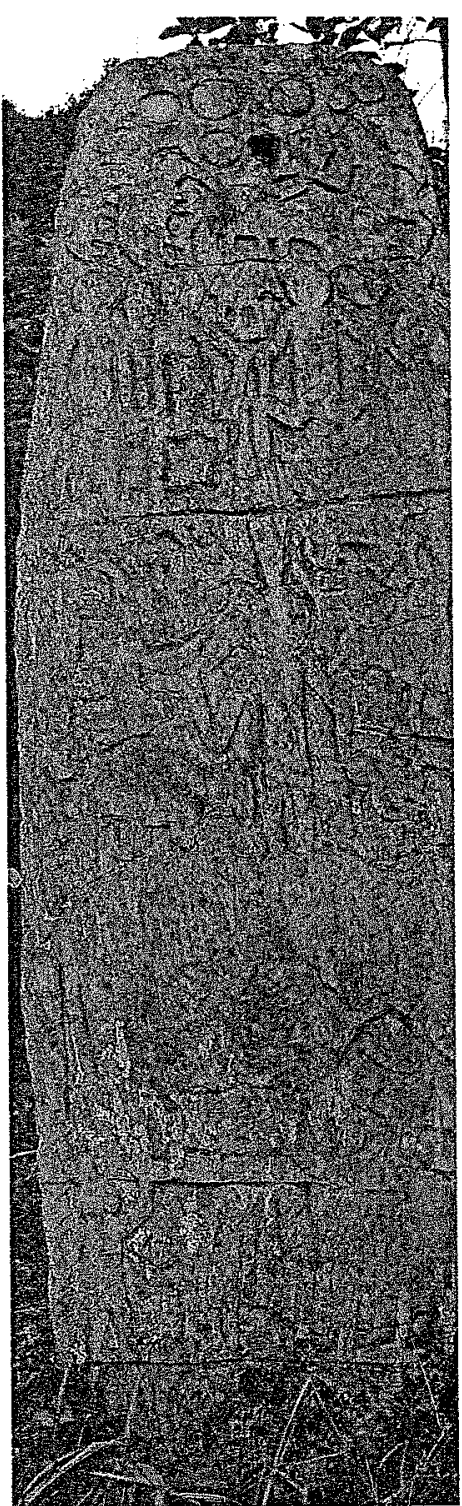

Figure 4 steles triptych-(H.1. path. Mualbem (Tedim), front $2.33 \mathrm{~m} \times \mathrm{W} .1 .62 \mathrm{~m}$ ) commemo the clan Sukte. 


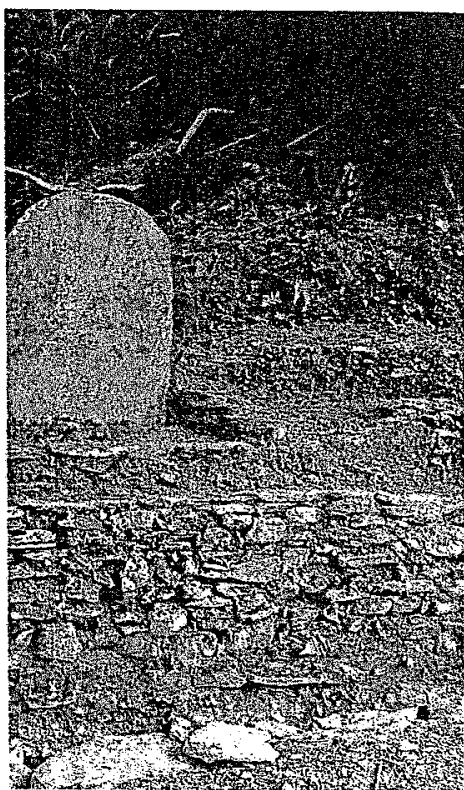

$1.60 \mathrm{~m}$ ) on promontories along

MB03 (Figure 24) and stele ¡ stele MB04 is situated just it the edge of the Saizangree-part structure. Undernd to allow for the stele to is a hunting scene full of al gongs. The central and portrays two superposed Chan Thuam stands drinkan unidentified character achyderm. Partially buried : standing stone represents

plays the different feats of inting for elephants, water sntifiable animals. It also

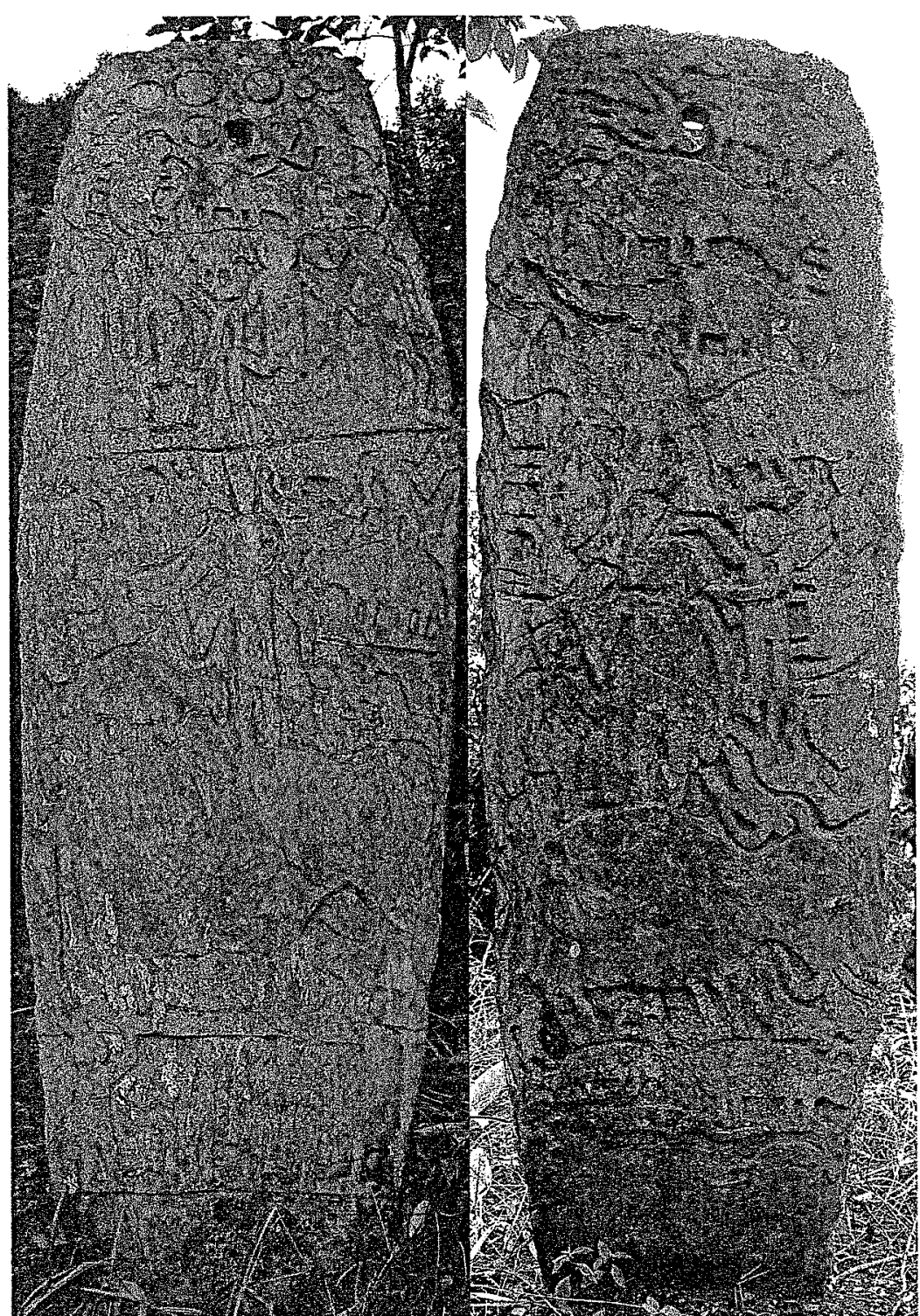

Figure 4 Steles triptych-(H. $1.2 \mathrm{~m} * W .0 .6 \mathrm{~m})$, - on the Tashon-Ealam path. Mualbem (Tedim), front and reverse sides of the MB04 stele ( $\mathrm{H}$. $2.33 \mathrm{~m} \times \mathrm{W} .1 .62 \mathrm{~m}$ ) commemorating the chief (hausa) Khan Thuam of the clan Sukte. 
shows the capture of slaves, shown naked and head to tail, and intertwining with the animal motifs.

\section{Upper Part of the Stele: Illustrations of Feats of Arms}

Wildlife are depicted surrounding the central scene, including deer, hares, birds of all kinds, and sometimes bears (Figure 5); water buffaloes (Figure 6); rhinoceroses (Figure 7); and elephants (Figure 8$)^{5}$

Several characters are depicted naked, jumbled, and headto-tail, with their genitals prominently shown. They are the "slaves" captured following inter-clan wars or village raids. Four of them are represented that way across the upper right

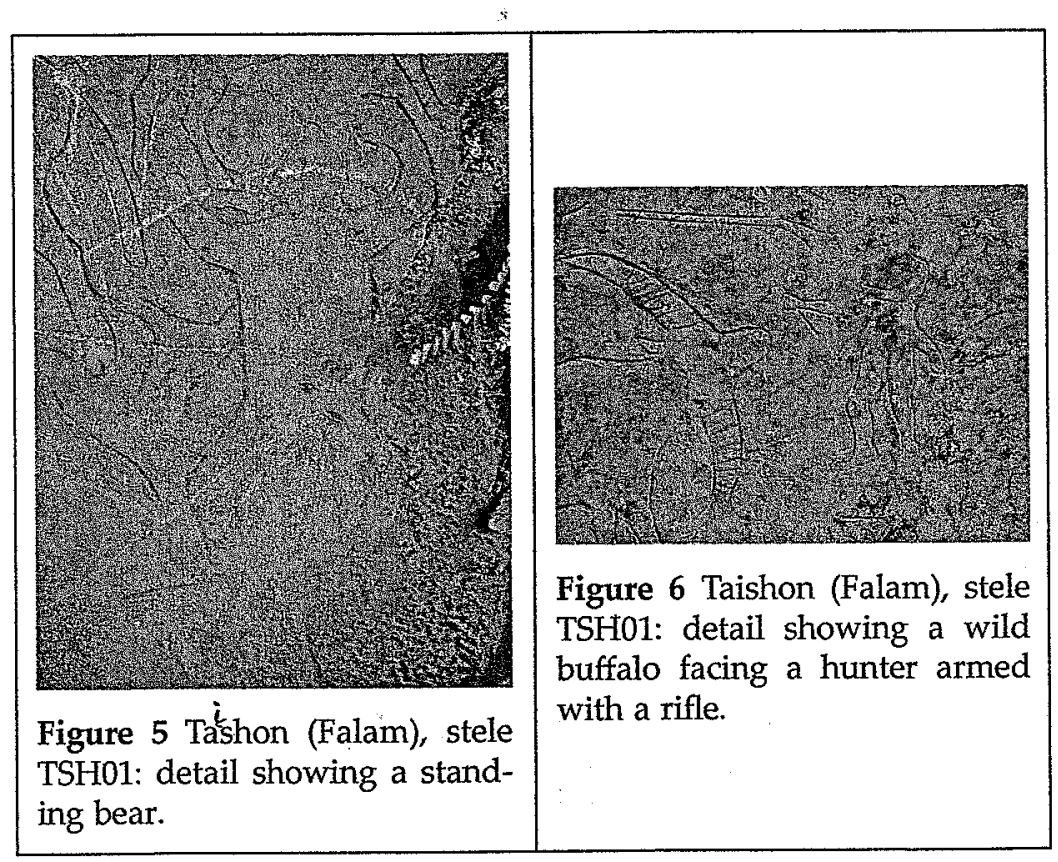

5 According to Bareigts (1981), the last rhinoceros was shot in 1895. Stela SZ02, on which is represented a rhinoceros on the top right, bears an inscription with the year 1911 carved in stone. This trace of writing, the only one on the stone, was probably added shortly after its erection.

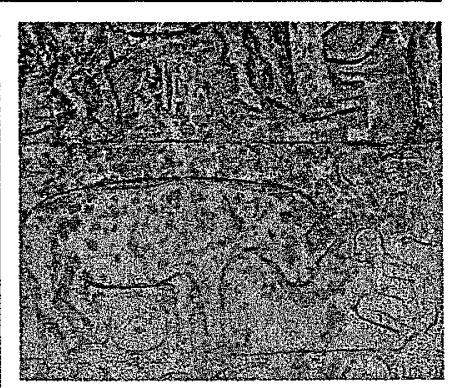

Figure 7 Saizang, (Tedim), s SZ02 (lower part of the fro rhinoceros.

border of stele SZO2 (Figu portrayed within a huntir in head-to-tail unnatural humiliation forced upon $i$ of the line for those charar stele from Mualbem wher on all fours (Figure 14).

Among military feats, rarely commemorated one This is probably due to $t]$ raids were among the arg government to justify senc a couple of steles were for of head-hunting as done $i$ and Tedim. In the village villager to his home. $\mathrm{He}$ stones of his courtyard, fi: rainy season. The hidden $s$ showed a one-of-a-kind er phant calf protected by an : standing on his back. The indicates that the man is a on one side the body of 1 other, his head (Figures 1 
wn naked and head to tail, I motifs.

\section{lustrations of Feats}

g the central scene, includids, and sometimes bears :6); rhinoceroses (Figure 7);

naked, jumbled, and headiently shown. They are the -clan wars or village raids. way across the upper right

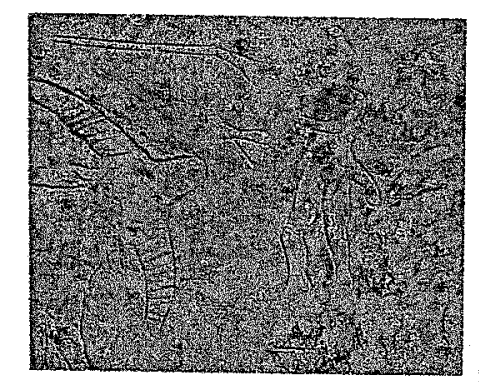

,ure 6 Taishon (Falam), stele 101: detail showing a wild falo facing a hunter armed $\mathrm{h}$ a rifle.

inoceros was shot in 1895. Stela ros on the top right, bears an itone. This trace of writing, the d shortly after its erection.

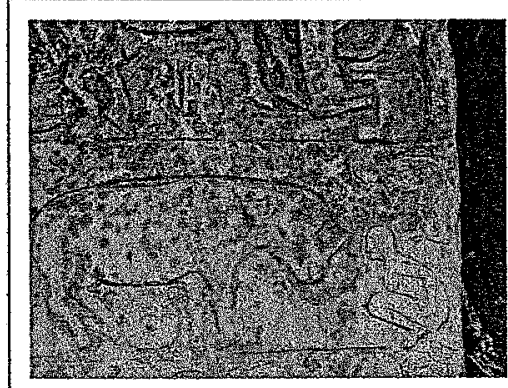

Figure 7 Saizang, (Tedim), stele SZ02 (lower part of the front): rhinoceros.

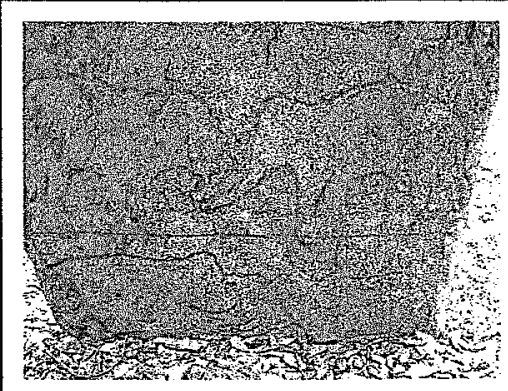

Figure 8 Tualzang, stele TLZ: elephants.

border of stele SZ02 (Figures 9 to 11). The fact that they are portrayed within a hunting scene conspicuously naked and in head-to-tail unnatural postures is meant to heighten the humiliation forced upon them. In the same way, the stroke of the line for those characters is accentuated as seen on this stele from Mualbem where a dog sniffs the anus of a person on all fours (Figure 14).

Among military feats, head-hunting is one of the most rarely commemorated ones and its depictions remain a rarity. This is probably due to the fact that slavery and inter-clan raids were among the arguments put forward by the British government to justify sending military troops. Nevertheless, a couple of steles were found that did illustrate the practice of head-hunting as done in the past in the regions of Falam and Tedim. In the village of Gawng Mual, I was invited by a villager to his home. He then began to unseal one of the stones of his courtyard, fixed there to avoid the mud of the rainy season. The hidden side, smoothed by the water runoff, showed a one-of-a-kind engraved motif. It displayed an elephant calf protected by an adult pachyderm, which has a man standing on his back. The nearby spear on the illustration indicates that the man is a warrior. He holds at arm's length, on one side the body of his decapitated enemy and on the other, his head (Figures 15 and 16). 


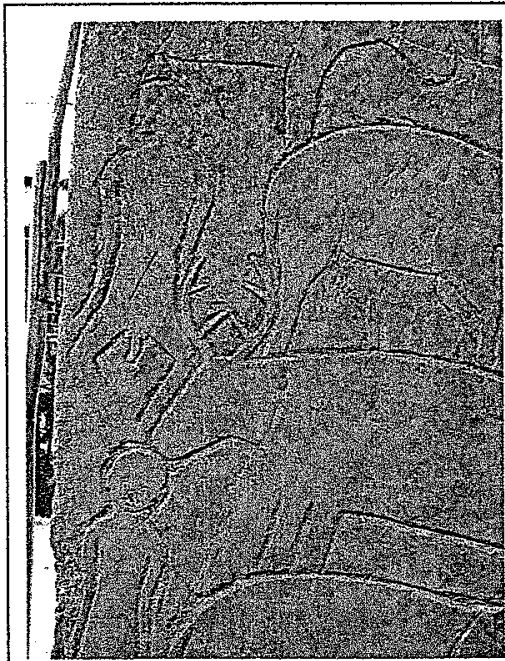

Figure 9 Saizang (Tedim): detail of the stele SZ02 (front) commemorating Do Tual.

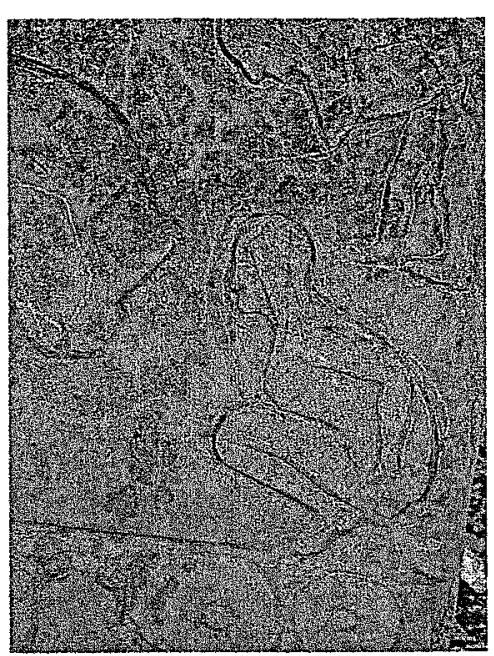

Figure 11 Saizang (Tedim): detail of the stele SZO2 (front) commemorating Do Tual.

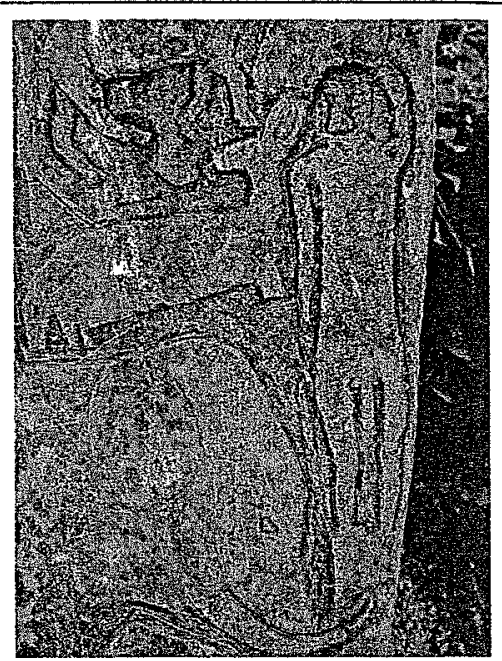

Figure 10 Saizang (Tedim): detail of the stele SZ02 (back) commemorating Do Tual.

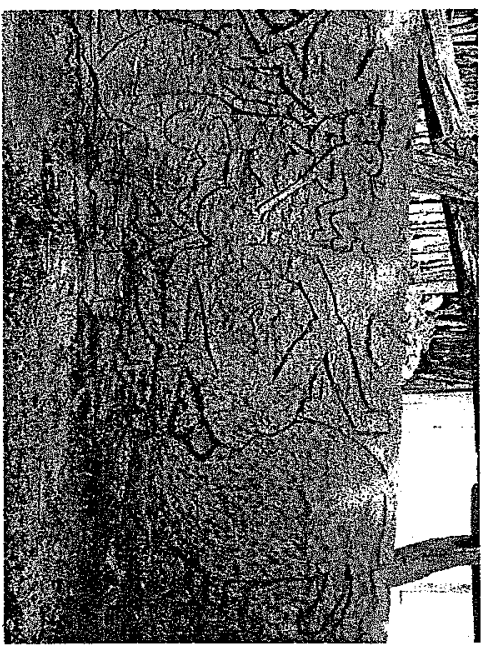

Figure 12 Mualbem (Tedim): detail of the stele MB03 (back) commemorating Za Khai.

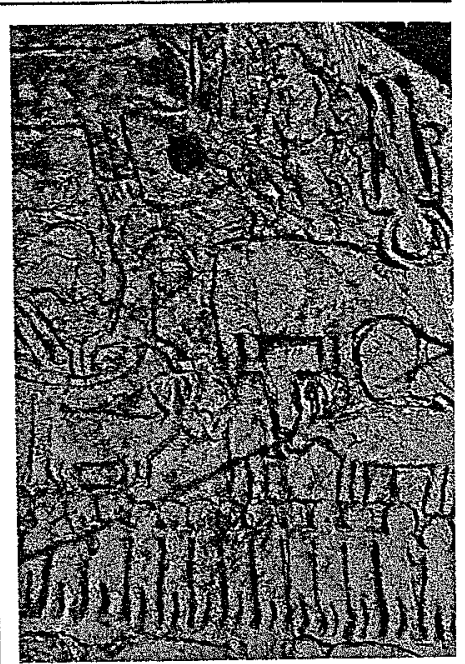

Figure 13 Mualbem (Tedin detail of the stele MB09 (back)

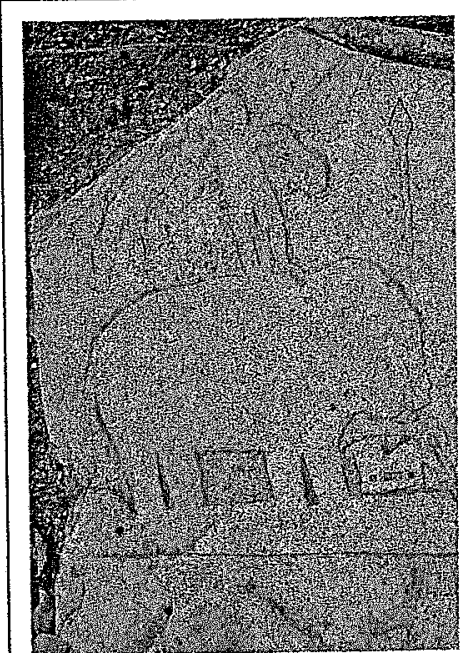

Figure 15 Gawng Mual (Ted: stele GML03. 


\section{Central Part of the Steles: Shamanic Voyage}

Around Falam, below the village of Sunthla, a group of three abandoned steles has completely disappeared under the vegetation (Figures 17, 18, and 20). The fact that no hole has been drilled at their peaks means that they were probably carved and engraved onsite. Their significant mass helps distinguish them from other steles. The largest of the three is about twometers high and one-meter wide. It is thick enough-about 20 centimeters - for both its rims to feature engraved designs. One rim shows fish swimming in the water, with overlooking birds and deer, while the other displays a human head identical to the ones visible on the main sides. The style of the steles is very stark with only a thin engraved line to show the outline of the face, and simple horizontal lines to symbolize the eyes and the mouth (Figure 16) 20).

The minimalist style of these faces is found again in the same region, as with the steles in Taishon. Instead of faces, those stones show several human figures arranged one above the other that stand as sculptures in the round atop wooden masts dedicated to deceased clan members and their respective ancestors. The square structure of certain posts suggests that the most recent ones date from the 1950s or 1960s (Bareigts 1981). One of them had been set down on the ground, at the foot of one of the cobblestoned promontories found along roads that tend to be carried off to cities to be sold at the antiquities markets. This post was the last of a set of 14 or 15 others which still stood upright, alongside the steles, at the time of my research. At its peak was depicted a man's head, recognizable by the fact his hair was in bun, then was shown a bust adorned with necklaces, and a set of five superimposed heads that symbolized and commemorated as such the ancestors of the deceased (Figures 19, 21, and 22). The very unique style is not characteristic of the region of Falam. It is, however, found in the region of Hakha on wood carvings commemorating a specific person, or sometimes a whole family, with moving details representing their deceased infants.

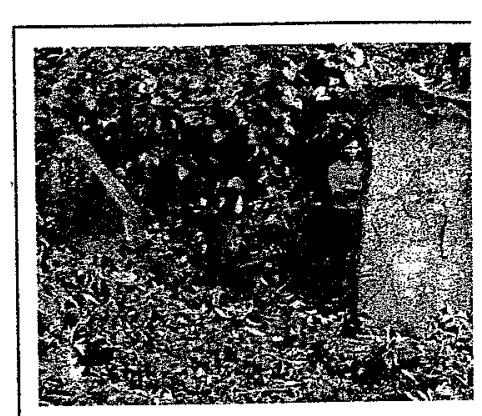

Figure 17 Sunthla, steles 01 a 02 (reverse side).

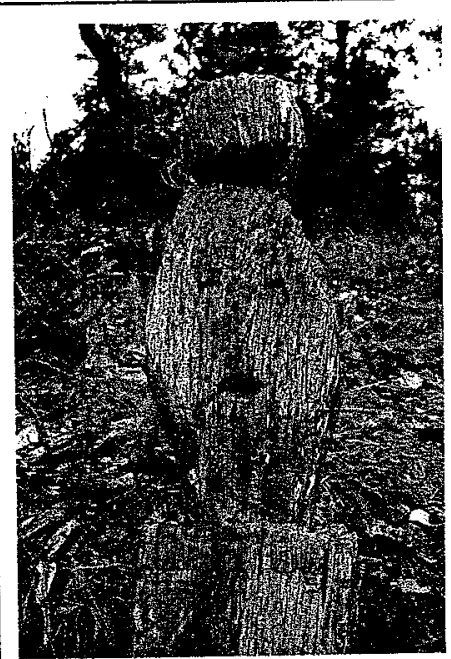

Figure 19 Hniarlawn (Hakl detail of the post. 


\section{Shamanic Voyage}

of Sunthla, a group of three disappeared under the vegre fact that no hole has been they were probably carved cant mass helps distinguish st of the three is about two$\therefore$ It is thick enough-about o feature engraved designs. the water, with overlooking isplays a human head idenrain sides. The style of the $n$ engraved line to show the Jrizontal lines to symbolize 6) 201.

faces is found again in the I Taishon. Instead of faces, figures arranged one above in the round atop wooden members and their respecre of certain posts suggests from the $1950 \mathrm{~s}$ or $1960 \mathrm{~s}$ ad been set down on the sobblestoned promontories e carried off to cities to be is post was the last of a set sod upright, alongside the At its peak was depicted a fact his hair was in bun, vith necklaces, and a set of mbolized and commemo: deceased (Figures 19, 21, $s$ not characteristic of the and in the region of Hakha ing a specific person, or loving details representing

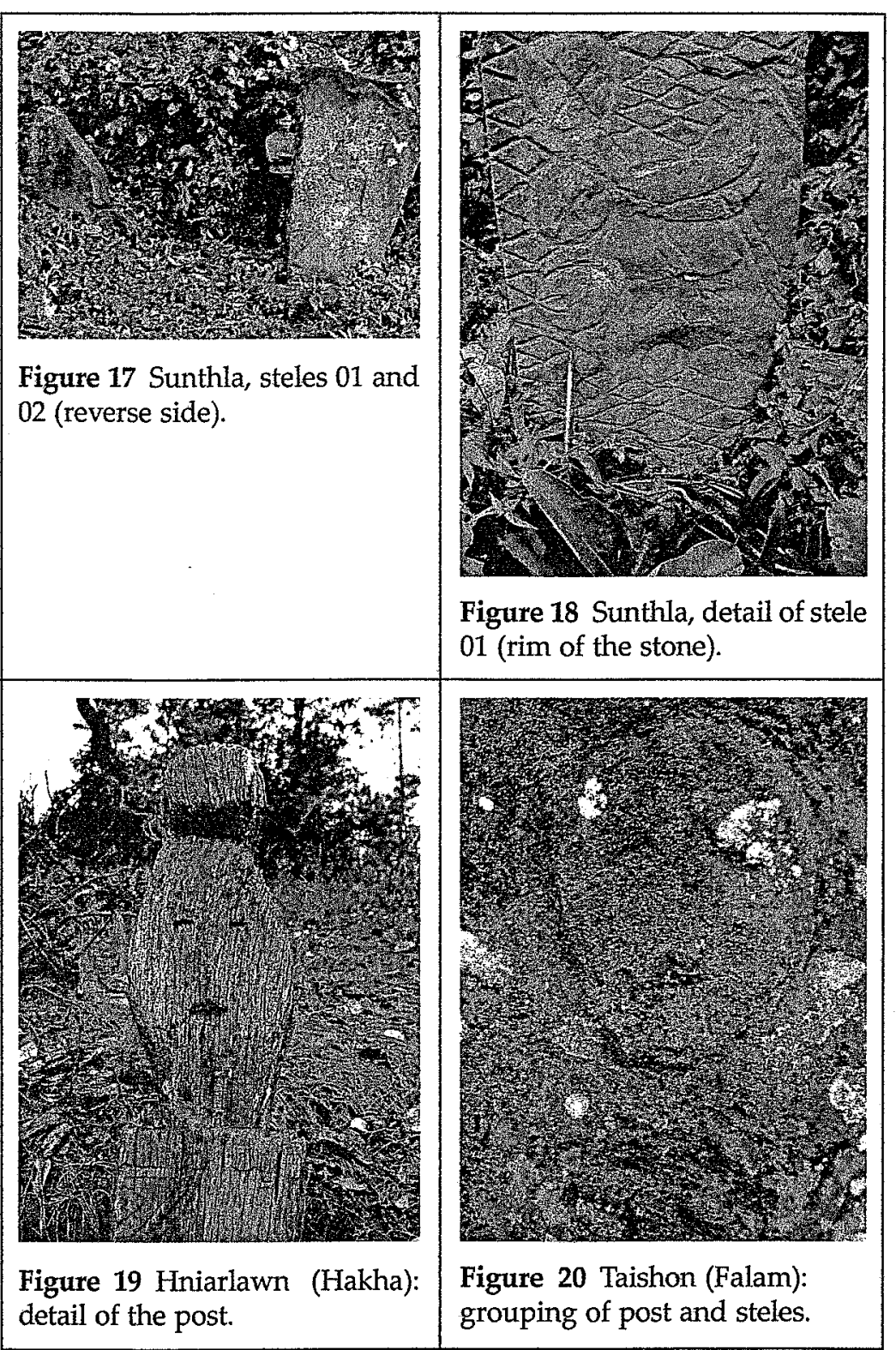




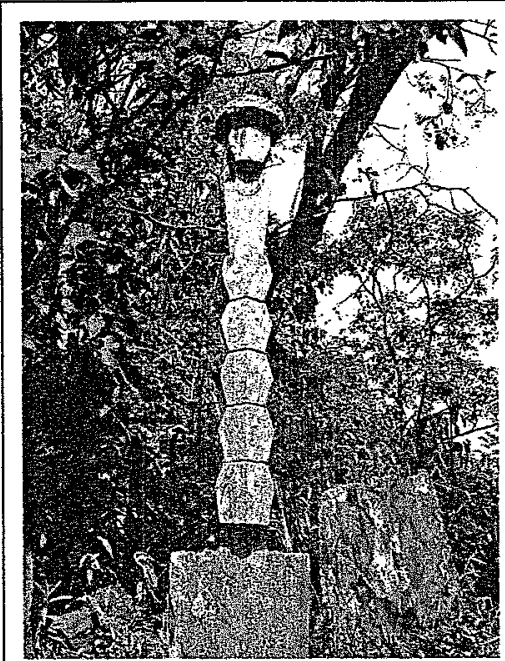

Figure 21 Taishon (Falam): grouping of post and steles.

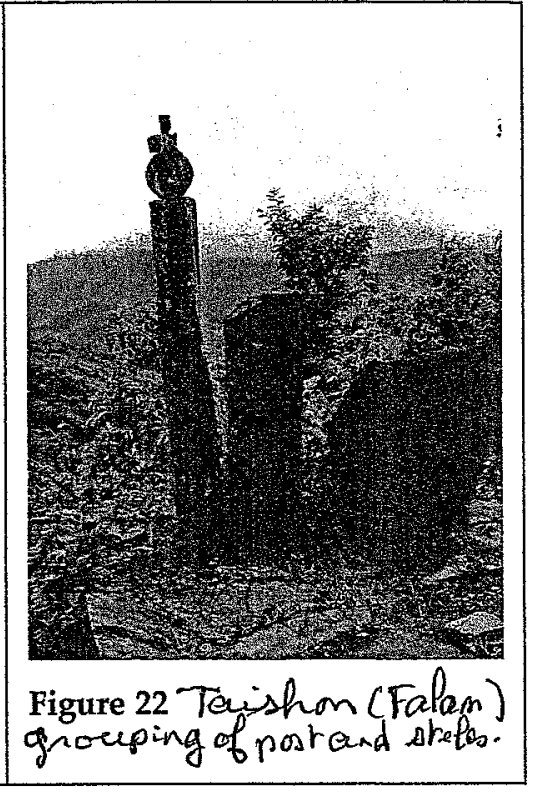

In contrast, a completely different morphology and another style of memorial art may be observed in the region of Tedim in the north of the Chin State. At the same time, the main themes of praise for the deceased hero, ancestrality, and clan solidarity, and the steles' positioning along the road, remain constant.

The stele SZ02, which was the original basis for this study, overlooks the main road of the village of Saizang. It is a high monolith over two meters in height and ten centimeters in thickness. Its center depicts a family of three people (Figures $7,9-11,23,33$ ). One can observe the father grabbing a jar of alcohol that is being handed to him by his wife-a theme frequently shown on other steles-while the child is seen affectionately holding his mother's arm. The couple is standing upon the back of an elephant, while the child stands on an elephant calf. The pachyderm was the mount the deceased rode on their shamanic journey, which was believed to take them back to the land of their ancestors. Gongs of different diameters encircle these three characters. It is a clear depic- tion of the ritualistic exchas exchange of women, who: the status of those involve

Motifs depicting a unite are found on almost all stc plays on the same side, 1 scenes: dead members of a their vehicle pointed towa holding hands or opening the legs of the mother whe moving depiction of a still

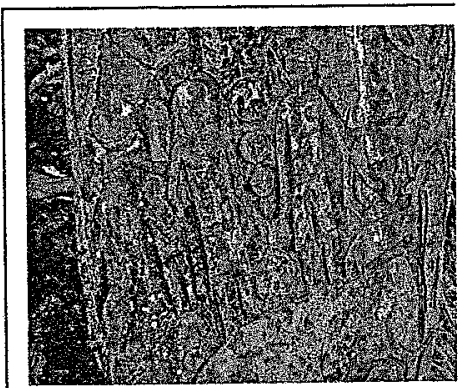

Figure 23 Saizang (Tedim): detail of stele SZ02, chief Do Thual, clan Sukte.

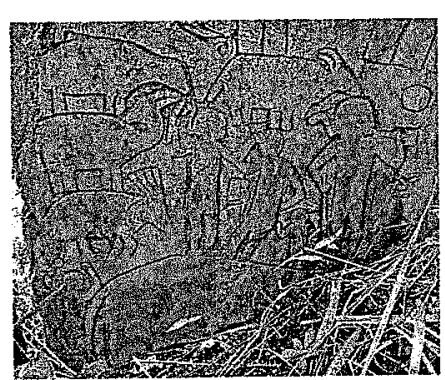

Figure 25 Mualbem (Tedim): detail of stele MB01, Thang 2 Liang of the clan Sukte. 
tion of the ritualistic exchanges of goods during the inter-clan exchange of women, whose dimensions are proportional to the status of those involved as wives-"takers."

Motifs depicting a united family as well as clan solidarity are found on almost all stones. In Mualbem, stele MB03 displays on the same side, one above the other, two similar scenes: dead members of a family stand atop of an elephanttheir vehicle pointed toward the country of the ancestorsholding hands or opening jars of alcohol, while in between the legs of the mother who probably died in childbirth is the moving depiction of a stillborn infant (Figure 24).

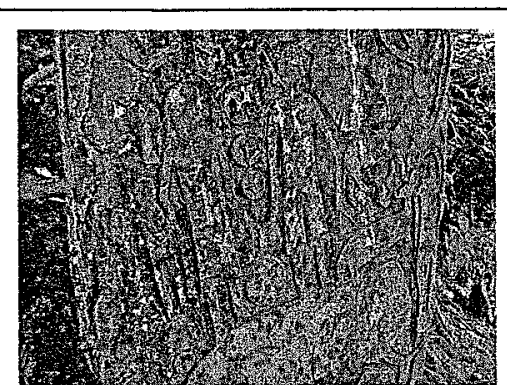

Figure 23 Saizang (Tedim): detail of stele SZ02, chief Do Thual, clan Sukte.

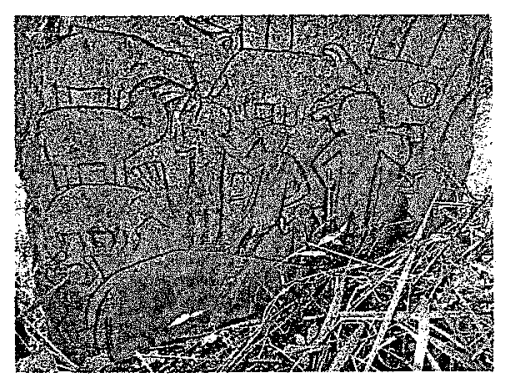

Figure 25 Mualbem (Tedim): detail of stele MB01, Thang Za Liang of the clan Sukte.

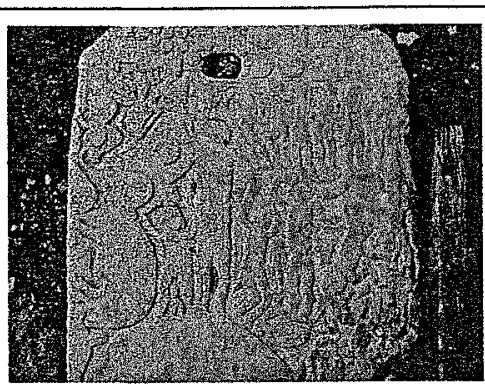

Figure 24 Mualbem (Tedim): detail of stele MB03, chief $\mathrm{Za}$ Khai, clan Sukte.

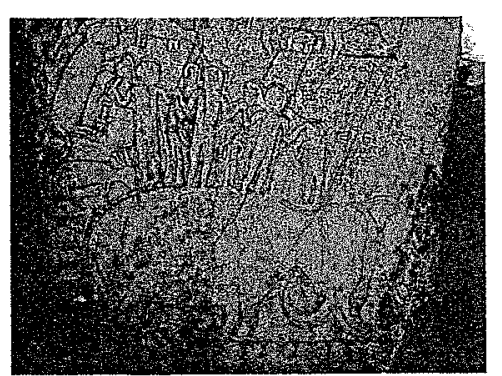

Figure 26 Mualbem (Tedim): detail of stele MB02, representing chief Lam Pau of clan Khup $\mathrm{Mu}$ (d. 1923). 


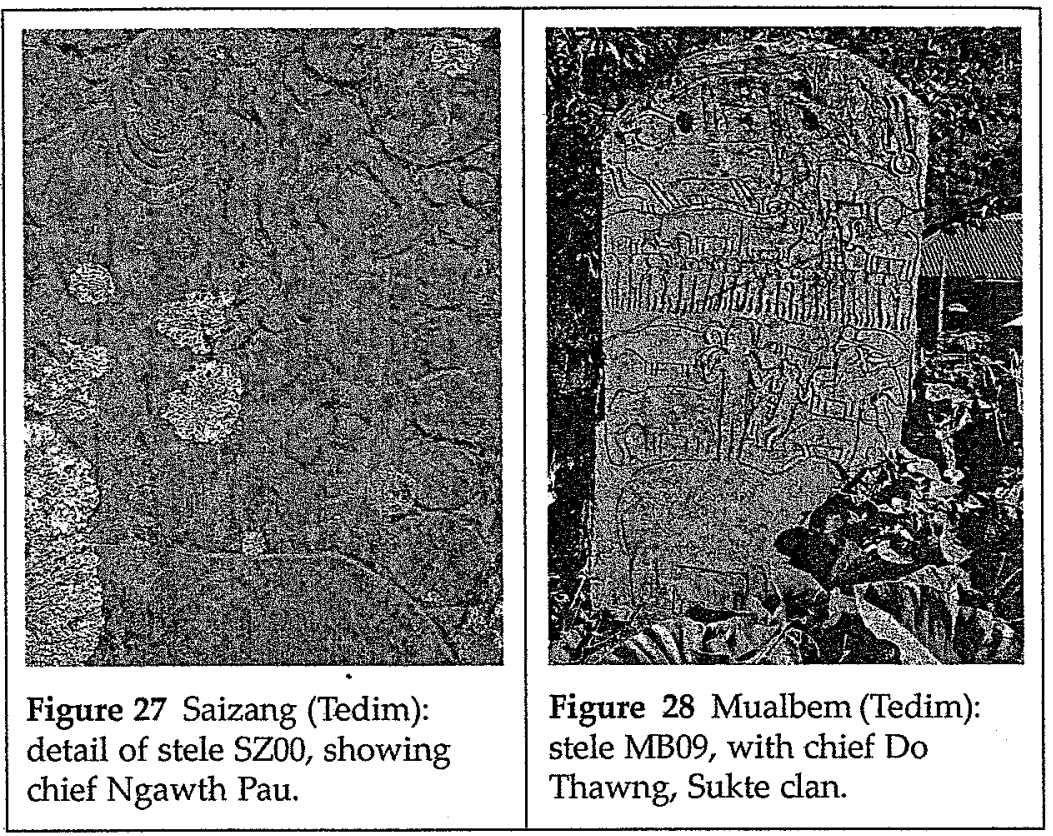

\section{Lower Part of the Steles: Clan Networks}

Curiously, among the authors whose works are considered authoritative on the subject, Stevenson (1938) only briefly mentions standing stones, ignoring how the erection of such steles would give rise to important collective clan ceremonies. Such ceremonies would involve notable dignitaries; as well as highly codified redistribution networks for exchanges of goods, which would vary according to different degrees of kinship and support groups (Head 1955; Danel-Fédou and Robinne 2007).

Several vernacular terms succinctly identify the different forms of clan solidarity. In the region of Hakha, where Lai is spoken, the expression hlaw bung refers to the idea of people working together, without sharing any family ties, while the term seu specifically references groups working together on the construction of a house, doing fieldwork, etc., who come together as members of the same clan. In the region of Tedim, the term lo kilawm alludes to a group of youths who come together for the clearing necessarily from the same kihuh, which refers to a si tance to village members installation of a new roof o has health issues, etc.). W mutual reciprocity, kihuh d referencing various suppc terms that express various rights and duties. Thalloh $c$ bears responsibility for the of my wife, who must sar riage; while thusa naw zaw engaged in various kinds c within the village (Danel-F

Clan solidarity is theref Chin society, and it is this depicted in the lower part interconnects steles across

\section{Clan Territorialities}

\section{Genealogical Depth}

For societies that have an c ing stones serve as a pillar permitting the identificatio front and back sides of the its rims if they are thick $\mathrm{e}$ primary understanding of living descendants of thos onstrate the genealogical d documents. Among the $\mathrm{m}$ in particular enabled me tc existed between the steles village of Saizang.

In the village of Mualbe Mang (stele MB06), grand 
together for the clearing of fallow lands but who are not necessarily from the same clan. Another Tedim expression is $k i h u h$, which refers to a support group giving ad hoc assistance to village members (helping, for example, with the installation of a new roof or providing farm labor if someone has health issues, etc.). While lo kilawm implies a duty for mutual reciprocity, kihuh does not. The different designations referencing various support groups are complemented by terms that express various degrees of kinship, based on one's rights and duties. Thalloh designates the oldest brother, who bears responsibility for the family; sungpi refers to the father of my wife, who must sacrifice an animal during my marriage; while thusa naw zaw alludes to the neighbors who are engaged in various kinds of reciprocal support relationships within the village (Danel-Fédou and Robinne 2007: 30-4).

Clan solidarity is therefore one of the very foundations of Chin society, and it is this theme that is not only invariably depicted in the lower part of a standing stone, but that also interconnects steles across the same or various sites.

\section{Clan Territorialities}

\section{Genealogical Depth}

For societies that have an oral tradition, the engraved standing stones serve as a pillar to support collective memory. By permitting the identification of the people represented on the front and back sides of the stele, sometimes even depicted on its rims if they are thick enough, oral traditions allow for a primary understanding of the history behind the stones. The living descendants of those characters carved in stone demonstrate the genealogical depth of which the steles are in situ documents. Among the many informants interrogated, two in particular enabled me to understand the continuity which existed between the steles of the village of Mualbem and the village of Saizang.

In the village of Mualbem, Lian Cin Dal, son of Thuam Za Mang (stele MB06), grandson of $\mathrm{Za} \mathrm{Pau} \mathrm{(+1882)} \mathrm{and} \mathrm{great-}$ 
grandson of Khan Thuam (stele MB04), recited from memory and then wrote down for me 15 genealogical levels, both ascending and descending, even including the name and clan of the spouses of his ancestors. While this fact is remarkable, it is likely not unique (Pascal Bouchery 1995: 28-38). It is actually based on a mnemonic names-cum-datation process, which assigns the last syllable of the name of the father of the father to the first syllable of the name of his grandson; this vernacular kinship terminology describes this relationship between the grandfather and his son in the masculine line of "pu tu." This incorporation of a clan subject in the patrilineal filiation-as well as the reattachment of the clan to the territory-shows the very finality of the sacrificial ceremonies organized during the erection of stones.

In the village of Saizang, locals apprised a sprightly 74-year-old elderly woman, of my presence. Man Za Go was dressed simply in a white jacket, a draped local skirt, a stole in faded colors, and well-used sandals, the only outward sign of her lineage being several strands of long amber necklaces. She then devoted hours reviewing the engravings depicted on the steles, leading me from stone to stone, while she recounted both personal memories and stories that spanned many clan generations and had been preserved through the collective memory. The interest created by the engravings proved communicative, as gawkers started to gravitate around our small team, with many of them never having truly surveyed the stones they passed every day. Both children and adults amused themselves by tracing with their fingers the contours of the features on the steles, interpreting every detail engraved on both sides, commenting on scenes of an everyday life in which they recognized themselves, and laughing at the characters depicted naked.

These oral sources were supplemented by written sources which I had discovered only later: it was only after I had returned to France that the link between the standing stones and events relating to British colonialism (Carey and Tuck 1896; Crosthwaite 1912) became clear. The reason for this gap is that in spite of the high accuracy of the facts stated and of the genealogical trees whis names differs significantly from one informant to anc tion of written and oral sc dating (i.e. within a few : intersection of the sources and inter-clan alliances $\mathrm{w}]$

To better understand th what they tell us of Chin associated with the Sukte grouping is in the village resistance movements to second considers a groupi was under the supervisior were amongst the authori of Panglong, that led to $t$ Special Division. The thirc the village of Tonzang: Kanhow (Kam Hau) clan, mentation process.

The three sites are exa succession. This is done $f$ each succession fits contin also represents a fundame: created by the principl younger children inherit property, while the older The steles erected at the younger sons, while the s and Tonzang extol their $\epsilon$ ritorial expansion and neu they pay homage to the $h$

\section{Grouping of Standin! Tribute to the Young}

Following the annexation conquest of Mandalay ar 
304), recited from memory genealogical levels, both sluding the name and clan ile this fact is remarkable, ery 1995: 28-38). It is actues-cum-datation process, e name of the father of the ame of his grandson; this escribes this relationship in in the masculine line of $\mathrm{n}$ subject in the patrilineal int of the clan to the territhe sacrificial ceremonies ones.

als apprised a sprightly presence. Man Za Go was draped local skirt, a stole als, the only outward sign : of long amber necklaces. the engravings depicted tone to stone, while she and stories that spanned in preserved through the eated by the engravings ers started to gravitate ty of them never having sed every day. Both chil'es by tracing with their on the steles, interpreting $\mathrm{s}$, commenting on scenes zognized themselves, and naked.

lented by written sources : it was only after I had ween the standing stones rialism (Carey and Tuck ir. The reason for this gap of the facts stated and of the genealogical trees which I had found, the transcription of names differs significantly from one source to another, and from one informant to another. Besides the fact that duplication of written and oral sources allowed for the very precise dating (i.e. within a few years) of the standing stones, this intersection of the sources illustrates the segmental dynamics and inter-clan alliances which these steles reflect.

To better understand the nature of the standing stones and what they tell us of Chin society, three groupings of steles associated with the Sukte clan will be analyzed. The first grouping is in the village of Mualbem, where was born the resistance movements to the British invaders; while the second considers a grouping in the village of Saizang, which was under the supervision of Mualbem whose descendants were amongst the authorities who in 1948 signed the Treaty of Panglong, that led to the official recognition of the Chin Special Division. The third grouping of steles examined is in the village of Tonzang: named after the founder of the Kanhow (Kam Hau) clan, and representative of the clan segmentation process.

The three sites are examined in this article in a specific succession. This is done for several reasons. To begin with, each succession fits continuously in time. Furthermore, each also represents a fundamental element of social arrangement, created by the principle of ultimogeniture-where the younger children inherit paternal status and their parents' property, while the older sons go off to conquer new lands. The steles erected at the Mualbem site commemorate the younger sons, while the standing stones erected in Saizang and Tonzang extol their elders for their contribution to territorial expansion and new clan formations. At the same time, they pay homage to the heroes of anti-colonial resistance.

\section{Grouping of Standing Stones of Mualbem: Tribute to the Youngest}

Following the annexation of Upper Burma in 1885, with the conquest of Mandalay and the exile of King Thibaw, the 
"pacification" of the border regions that ensued decidedthrough two successive campaigns - the fate of the Lushai, the Lakher, and the Chin Hills. When Lian Cin Dal recited by heart for me the 15 levels of generations of his clan (Chart 1 ), the connection between his ancestors and the heroes of the resistance did not appear at first. Limiting ourselves to the characters who are listed in the family tree specifically honored by the steles, the story begins with Khan Thuam, the

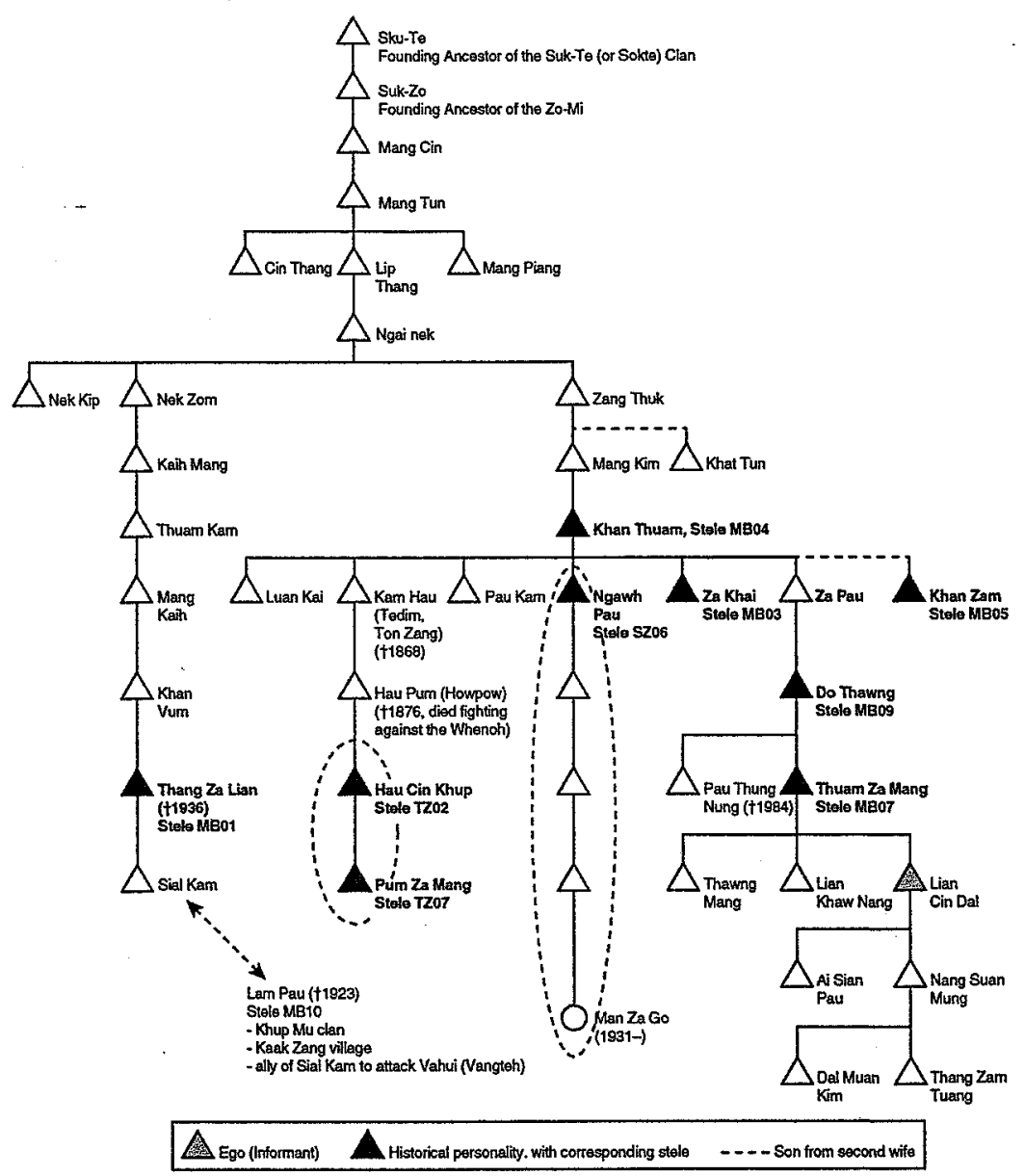

Chart 1 Mualbem and Tonzang, genealogical chart of Dal Cin Lian. eighth-generation descen history, Sukte (Sokte).

It is, seemingly, with tr of Elders of Tashon, ${ }^{6}$ to $\mathrm{W}$ Thuam succeeded his fath and Tuck [1896] 1976: 118as a skilled horseman $\mathrm{w}$ Manipur against the Yaho ern part of Chin State, wh greatest accomplishment ficiently important for the in his memory. Situated Mualbem, this stele is one a height of over two met on both its front and back main characters-Khan T] an elephant and surrour people: one is offering the the other is head-to-tail ar side are represented two both stand atop elephant stone portrays a hunting : ard series of characters, $s$ ting and thus contrastin portion of the stele that $s$. participating in a sacrifici

Khan Tuam left, follow count the one he had wit] the Khup Mu clan. The sn (or Kanyam), the son of $t$

6 Village below Falam. Its "den comparison to the chiefdoms . functioned under an "aristocrat nology of Leach.

7 The spelling of the names foll informant, with the British spethe two spellings sometimes di 
ns that ensued decided$\mathrm{s}$ - the fate of the Lushai, en Lian Cin Dal recited by tions of his clan (Chart 1), ors and the heroes of the Limiting ourselves to the ? family tree specifically ins with Khan Thuam, the

o(or Sokte) Clan

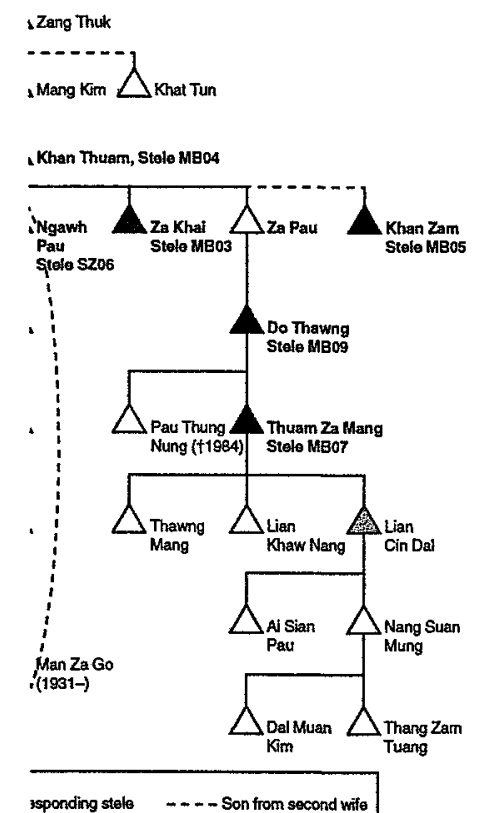

sgical chart of Dal Cin Lian. eighth-generation descendant of the founder of the clan history, Sukte (Sokte).

It is, seemingly, with the backing of the powerful Council of Elders of Tashon, ${ }^{6}$ to which he was a tributary, that Khan Thuam succeeded his father as the head of Mualbem (Carey and Tuck [1896] 1976: 118-9). Collective memory depicts him as a skilled horseman who conducted numerous raids in Manipur against the Yahow and Lushai, as well in the northern part of Chin State, whose conquests are presented as his greatest accomplishment (ibid.). His feats of arms were sufficiently important for the stele MB04 (Figure 3) to be erected in his memory. Situated at the entrance of the village of Mualbem, this stele is one of the most imposing in size, with a height of over two meters. It is also beautifully engraved on both its front and back sides. One can see on one side two main characters-Khan Thuam and his wife-standing atop an elephant and surrounded by animals, and two other people: one is offering them a drink as a sign of respect and the other is head-to-tail and is probably a slave. On the other side are represented two characters of different sizes who both stand atop elephants. The upper part of the standing stone portrays a hunting scene full of animals and a haphazard series of characters, some depicted as naked and squatting and thus contrasting with the lowest, partly buried portion of the stele that shows an engraved line of villagers participating in a sacrificial ritual to commemorate the dead.

Khan Tuam left, following his death, six sons-eight if we count the one he had with a second wife or concubine from the Khup Mu clan. The small stele (MB05) honors Khan Zam (or Kanyam), the son of this second wife, ${ }^{7}$ by depicting him

6 Village below Falam. Its "democratic" organization stands out starkly in comparison to the chiefdoms that made up the Tedim area and which functioned under an "aristocratic" type of system: according to the terminology of Leach.

7 The spelling of the names follows that of the ones indicated to me by my informant, with the British spellings in brackets. The differences between the two spellings sometimes did not make it easy to make the connections 
standing on the elephant that is expected to take him to the ancestral land of the dead, and surrounded also by wild elephants and other animals, as well as by naked slaves.

The youngest son of Khan Tuam, chief Za Pau (Yapow) is not commemorated on any steles. We only know, that he joined the alliance between the Kanhow (Kam Hau), the Sukte, and the Siyin to fight off Manipuris, whose forces had seized Tedim (Carey and Tuck [1896] 1976: 120-1); and that he died in 1882 without any further details.

The stele MB09 was erected for the youngest son of $\mathrm{Za} \mathrm{Pau}$, Chief Do Thawng. While toward the end of his life he swore allegiance to the British, it was not without defending the honor of his clan beforehand. Carey and Tuck ([1896] 1976: 38) report at least two occasions where the village of Mualbem was invaded and then abandoned by chief Do Thawng and his men, who refused to surrender. During a third attempt to "hold peace talks," the British found both the villages of Dabon and Mualbem burning: "thirty-seven houses, which escaped the flames, were burned that night by the Chins themselves, who agreed that all must suffer alike" (Carey and Tuck).

Stele MB07 was erected in honor of the younger son of Do Thawng, Chief Thuam Za Mang (1905-58). The inscription in English recalls that he was recognized as hereditary chief by the British authorities, and held this position from 17 December 1925 to 4 January 1948. It also states that he captured a slave and killed many wild animals. For his funeral, no less than two buffaloes, two mithan, eight cows, and one pony were sacrificed conjointly in his name by members of the Sukte (Sokte) and Nguite (Nwite) lineages. The back of the stele displays the hunting feats which contributed to the reputation of Thuam Za Mang, with his prey-an elephant, rhinoceros, deer, boar, tiger, monkey, and toucan-now engraved in stone.

between the genealogies as recited and transcribed in local interviews, and the ones which appeared in written works. However, there is no question of the connections between the two.
The stele (MB03) is a trit Ya Khai (Khai Za), who pa neighboring Manipur. The the stele, pictured among animals, was identified $b$ : prisoner. The front side is ping characters, each stan, to say which one is $\mathrm{Ya} \mathrm{K}$ indeed that is who the sec

\section{Saizang Grouping of Clan Continuity Carn}

Among Khan Thuam's e second marriage, the fou dants-have had steles e] honor. Of the four eldest : Kam Hau - had children as conquest of new territorie!

Ngawh Pau (Nopow) I influence grew under his a and SZ06, Figure 2) standi Saizang led me to conduc generation descendant thi Pau, began by leading $m \epsilon$ where stood side by side, half-covered by vegetatior SZ06). Neither bore any tri two (stele SZ06) had engra on the stones have becomr as well as weathering, but were in fact meant as an $h$ clan, and to his wife Thu

8 Saizang today has eight clans Sih Zang, Zo, Gual Ngo, Zho No, Ging, Hat Lang, Min Suang, $\mathrm{Ha}$ Neu, Thawm, and Tang Pua. 
pected to take him to the urrounded also by wild $: 11$ as by naked slaves. 1 , chief $\mathrm{Za} \mathrm{Pau}$ (Yapow) is We only know, that he ianhow (Kam Hau), the nipuris, whose forces had 36] 1976: 120-1); and that $r$ details.

te youngest son of $\mathrm{ZaPau}$, te end of his life he swore it without defending the sy and Tuck ([1896] 1976: re the village of Mualbem by chief Do Thawng and During a third attempt to und both the villages of irty-seven houses, which that night by the Chins st suffer alike" (Carey and

- of the younger son of Do 105-58). The inscription in zed as hereditary chief by ; position from 17 Decemstates that he captured a s. For his funeral, no less ight cows, and one pony lame by members of the lineages. The back of the ch contributed to the repi his prey - an elephant, nkey, and toucan-now

Iscribed in local interviews, and . However, there is no question
The stele (MB03) is a tribute to the fifth son of Khan Thuam, Ya Khai (Khai $\mathrm{Za}$ ), who participated in several raids against neighboring Manipur. The "giant" shown on the back side of the stele, pictured among other slaves and who killed wild animals, was identified by my interlocutors as a Manipuri prisoner. The front side is largely covered by two overlapping characters, each standing on an elephant. It is difficult to say which one is Ya Khai and which one is his wife, if indeed that is who the second character is.

\section{Saizang Grouping of Steles: An Example of Clan Continuity Carried on by the Eldest}

Among Khan Thuam's eight sons, including one from a second marriage, the four younger ones-or their descendants-have had steles erected in Mualbem itself in their honor. Of the four eldest sons, only two-Ngawth Pau and Kam Hau - had children and distinguished themselves in the conquest of new territories (Chart 2).

Ngawh Pau (Nopow) led the village of Saizang, whose influence grew under his authority. The group of steles (SZ01 and SZ06, Figure 2) standing at the entrance of the village of Saizang led me to conduct this study: Man Za Go, a fourthgeneration descendant through the paternal line of Ngawh Pau, began by leading me down a street below the village, where stood side by side, on a promontory of dried stones half-covered by vegetation, were two high steles (SZ05 and SZ06). Neither bore any traces of writing and only one of the two (stele SZ06) had engravings on its front side. The features on the stones have become faint due to erosion from lichens as well as weathering, but one can still discern that the stones were in fact meant as an homage to Ngawh Pau of the Sukte clan, and to his wife Thule Vang of the Teizang clan. ${ }^{8}$ The

8 Saizang today has eight clans (beh): Sai Zang, Phai Leng, Dim, Teizang, Sih Zang, Zo, Gual Ngo, Zho No, and 12 lineages: Gual Nam, Suk Te, Tawm Ging, Hat Lang, Min Suang, Hak Kile, Song Lam, Kik Kai, Vang Aw, Mal Neu, Thawm, and Tang Pua. 


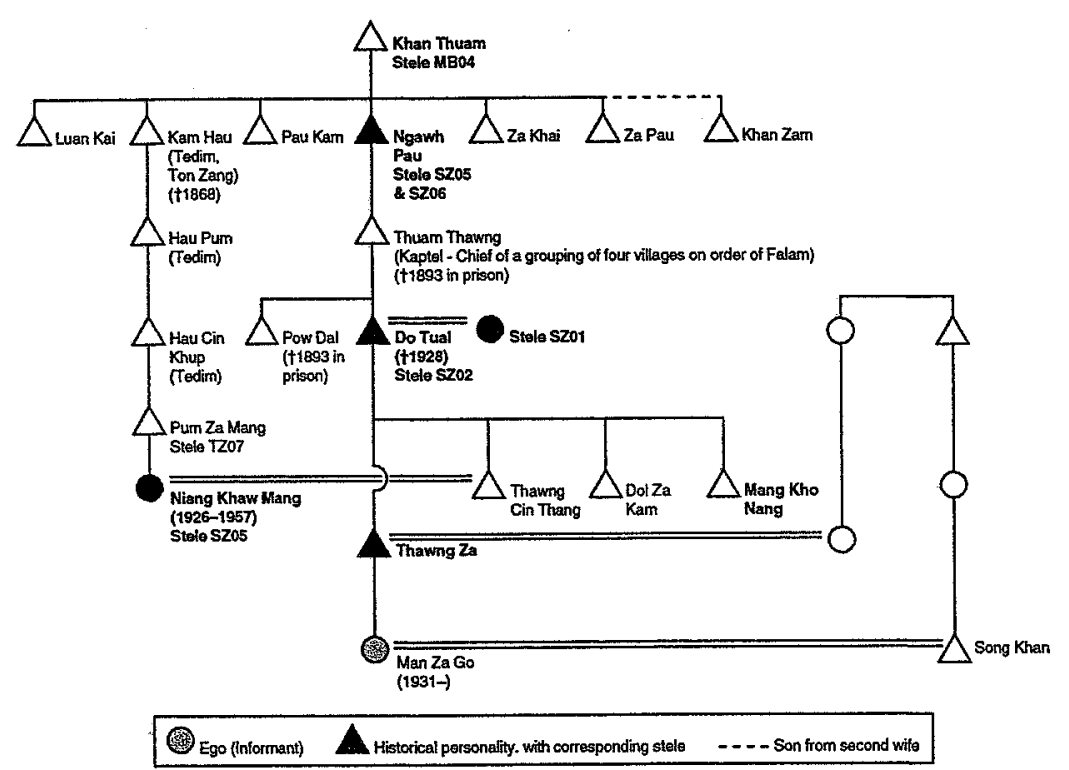

Chart 2 Saizang, genealogical chart of Man Za Go.

lines on the engraving are delicate. Ngawh Pau is seen standing on an elephant, with his torso covered with several necklaces, and next to a smaller character who is quenching his thirst. All across the central scene, gongs as well as animals, including a buffalo and a wild elephant, are depicted. The stones have no dates that would allow us to tell precisely when they were erected, or if that was even at the same time.

Out of the four steles that make up the site, it is the paternal grandparents of Man Za Go to which two (SZ01 and SZ02) are dedicated. The first still standing is small and bears no inscriptions-unlike stele SZ02-and is dedicated to Do Thual. Both its sides are covered with engravings of people and animals. A careful observation of the stele allowed us to discern a discrete, though clumsy, engraving of the date of the stone-13 November 1928-etched on the right side near the buffalo. That inscription is the only trace of writing on this standing stone, which is covered with etched patterns.
The two neighboring s recent manufacture and a1 Khaw Mang (1926-57) of Tonzang, the wife of Thi Saizang, and to Thawng Man Za Go. The latter was ing Saizang's head in 1928. of the Treaty of Panglong, Special Division and witt territory: attributed not to $\mathrm{c}$ whose name now became sacrifices made during the ing him were proportion: elephant (sai); three bisons wild animals altogether. $\mathrm{T}$. 15 mithan (sial), four buffa 38 domestic animals.

The influence of the vil Sukte clan as a whole-ne and expeditions of conqr under the name Kam Ha Tedim and then Tonzang.

\section{Tonzang Grouping of Clan Segmentation $b$.}

Although we were not $a b 1$ northernmost part of $\mathrm{Cr}$ country, the influence of $t]$ rable from the Mualbem a Saizang where clan conti by the youngest, Tonzang Mualbem accomplished $b$. clan name to the inhabitar

Kam Hau, the second : himself by founding Tedir then Tonzang. Located in state, the village became $t$ 
The two neighboring steles, SZ03 and SZ04, are of more recent manufacture and are dedicated respectively to Niang Khaw Mang (1926-57) of the Kanhow (Kam Hau) clan in Tonzang, the wife of Thawn Cin Thang of Sukte clan in Saizang, and to Thawng Za Khup (1907-66), the father of Man Za Go. The latter was a teacher at Tedim before becoming Saizang's head in 1928. He was also one of the signatories of the Treaty of Panglong, which saw the creation of the Chin Special Division and with it, the ultimate recognition of a territory: attributed not to a clan, but to the entire Chin people, whose name now became enshrined in the Constitution. The sacrifices made during the erection of the stone commemorating him were proportionate to the level of his name: one elephant (sai); three bisons (zang sial); one gral (saza); or five wild animals altogether. This, in addition to one pony (sakoi), 15 mithan (sial), four buffaloes (lawi), and 18 cows (bawng), or 38 domestic animals.

The influence of the village Mualbem - and with it of the Sukte clan as a whole-never truly recovered from the wars and expeditions of conquest of the elder brother: known under the name Kam Hau (Kamhow), and the founder of Tedim and then Tonzang.

\section{Tonzang Grouping of Steles: An Example of Clan Segmentation by the Elders}

Although we were not able to go to Tonzang, situated in the northernmost part of Chin State and right before Naga country, the influence of the village and of its hero is inseparable from the Mualbem and Saizang sites. However, unlike Saizang where clan continuity with Mualbem was ensured by the youngest, Tonzang is a case of clan segmentation with Mualbem accomplished by the elders who attributed a new clan name to the inhabitants of a new settlement.

Kam Hau, the second son of Thuam Kam, distinguished himself by founding Tedim (Carey and Tuck 1932: 120), and then Tonzang. Located in the far north of the current Chin state, the village became the stronghold of the Kanhow clan 
(named after its founder, Kam Hau). This is where, in 1856, raids occurred against first the Manipur, and then four years later against the Tipperah. The numerous military feats of Kam Hau unleashed a new wave of reprisals by the British which led to the so-called "pacification" campaigns in Chin State starting 1887 (Carey and Tuck [1896] 1976: 44-5; Stevenson [1943] 1968: 12). The chief Kam Hau, of the Sukte clan, who died in 1868 and is buried in Tedim, was, without a doubt, one of the greatest heroes of the resistance against the British invaders. The imposing MB07 stele, with its massive dimensions and elaborate carvings, stands at the entrance to Mualbem to remind us of his legacy.

The allegiance process observed in the case of the younger branch of the Sukte clan repeats itself within the same generation in the Kanhow (Kam Hau) clan. Ko Chim, the youngest son of Kam Hau, quickly became an ally of the British, to the point of even supporting them during the Lushai campaign of 1871. When he died in 1891, his successor Hau Cin Khup, who has been described in British testimonies as "shy and inexperienced" (Carey and Tuck [1896] 1976: 126), had already sworn allegiance a year earlier to the invaders. As the ultimate token of submission, he became responsible for overseeing the construction and the maintenance of the road leading to Manipur (117). The steles depicting Hau Cin Khup (TZ02) and his son Pum Za Mang (TZ07) may be found in Tonzang (Chart 1 ).

\section{Memorial Metamorphosis}

\section{Monotheistic Re-appropriations of Ancestrality}

The history of the steles at Mualbem of Saizang and Taishon is closely related, as we have seen, to the twin processes of colonization and decolonization. This is how we should understand this tribute both to leaders who had fought against the pacification campaigns of the British Army, as well as a few decades later, also to their descendants who were involved in the signing of the Treaty of Panglong. The latter originated the first $C$ and with it, the creation of in the second constitution State.

Because it is inseparab. unsurprising that the histo the expansion, at the turn not only monotheistic reli; the messianic movement 1 of the prophet Pau Chin : with the beginning and $e$ mausoleum was built in th steles bear characters crea as a way to spread his tec

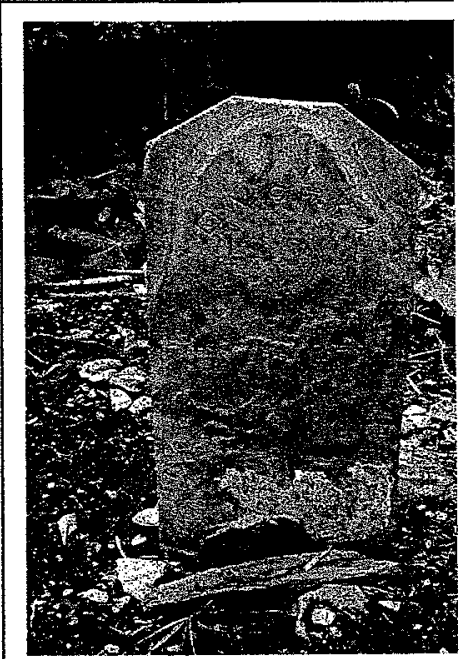

Figure 29 Stele bearing char ters from the messianic cult Pian (Mualbem).

9 On the history of the Lai Pian should also note that some oth language; evidently written pos ings (Figure 29). 
u). This is where, in 1856, ripur, and then four years imerous military feats of of reprisals by the British ation" campaigns in Chin [1896] 1976: 44-5; Stevenn Hau, of the Sukte clan, n Tedim, was, without a : the resistance against the ;07 stele, with its massive , stands at the entrance to y.

in the case of the younger self within the same genlan. Ko Chim, the youngie an ally of the British, to 1 during the Lushai cam11, his successor Hau Cin ritish testimonies as "shy ck [1896] 1976: 126), had ier to the invaders. As the became responsible for : maintenance of the road - depicting Hau Cin Khup (TZ07) may be found in

\section{ms of Ancestrality}

$\mathrm{n}$ of Saizang and Taishon to the twin processes of This is how we should eaders who had fought of the British Army, as , their descendants who Treaty of Panglong. The latter originated the first Constitution of independent Burma, and with it, the creation of the Chin Special Division - which in the second constitutional text in 1974, was renamed Chin State.

Because it is inseparable from the colonial dynamic, it is unsurprising that the history of these steles also accompanied the expansion, at the turn of the 19th and 20th centuries, of not only monotheistic religions such as Christianity but also the messianic movement Lai Pian. Rather strikingly, the life of the prophet Pau Chin Hau (1859-1948) begins and ends with the beginning and end of the British annexation. His mausoleum was built in the village of Mualbem, where some steles bear characters created de novo by the prophet himself as a way to spread his teachings (Figure 29). ${ }^{9}$ In contrast to

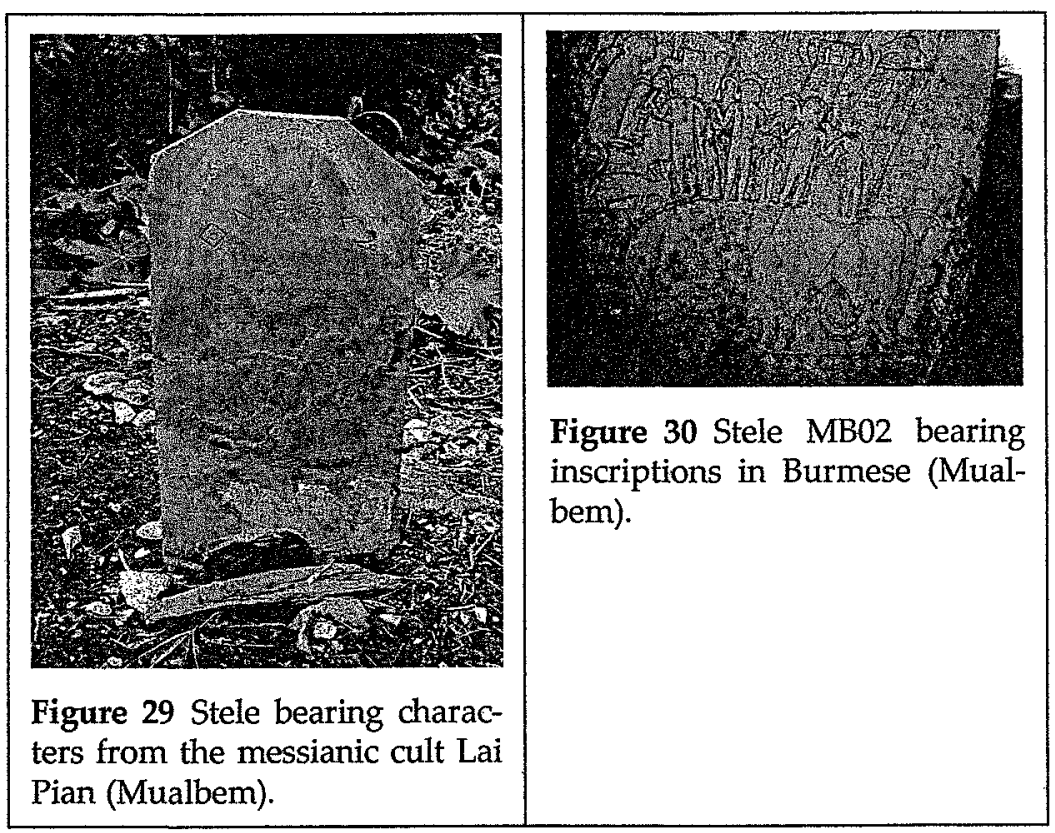

9 On the history of the Lai Pian writings, see Anshuman Pandey 2011. One should also note that some other steles bear inscriptions in the Burmese language; evidently written posteriorly, and covering in part the engrav-. ings (Figure 29). 
the lightning speed of its expansion in the Tedim region in northern Chin State, the influence of Lai Pian's messianic movement has continued to decline without completely disappearing. Even the creation in 2005 of the Sian Sawng secessionist movement did not entirely obliterate its existence. The concomitant development of Christianity in the country increased with the concurrent number of congregations, and their schismatic tendencies. One should remember that the first Baptists entered the Chin country in 1899 (Maung Shwe Wa et al. 1963: 385), while the Catholic presence, well evidenced in Hakha starting in 1891, only really intensified and developed after the 1950s (Bareigts 2003).

Man Za Go was converted to Christianity in 1937 when she was six. She was first a Baptist before becoming Catholic after her marriage in 1953 . While driving me from one stele to another, she took me to visit her old home. It was a true voyage through time, to which she had invited me, and an emotional journey for her which left a few discreet tears in the eyes of this humbled - though high-born by birthwoman. The house of Man Za Go now leans on steep slope on Saizang, alongside other houses of the same type. It is accessed through a narrow and slippery path and nothing in its sobriety helps distinguish it from other houses. The contrast is even more striking with the old and large family home situated on the embankment below. One can see the vast esplanade, surrounded by a balustrade and made of heavy, hand-hewn planks that extend the house itself and its dependence (Figure 32).

The traditional layout of the living space was the preserve of only the more affluent families; it is depicted almost exactly on a stele in the village of Tualzang (Figure 31). The stone shows a finely engraved central plaza where a mithan (Bibos frontalis) stands firmly attached to a sacrificial post, trying to escape its inevitable end. That scene takes place where there now stands the former residence of $\mathrm{Man} \mathrm{Za} \mathrm{Go}$, with the flag of the Jehovah's Witnesses aloft on a tall pole. The engraving on the stele also showcases clan members dancing and playing music on the lower flank of the perimeter: again, the

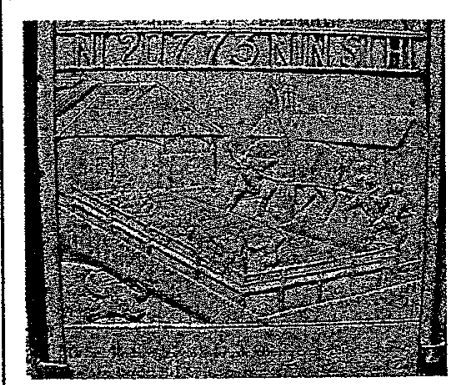

Figure 31 Tualzang (Tedim): sacrifice depicted on the esplanade of a house.

same place where preser tional school quietly take $t$ to enter the former privat ground. One can also see $\mathrm{c}$ roof of a house as well as which-modernized-stil struction materials change by corrugated iron. Fron masters of the house ha being clan leaders to des mental dynamics, therefc clan dimension being take without its essence havin

The steles have not esci In the village of Saizang, a of standing stones (Figure 1980 , at the initiative of the of Yangon for several dec cally speaking, an "exorci refer to a defunct shame political organization and they are not actual tombs altars erected to propitia their commemorative dir 
on in the Tedim region in ə of Lai Pian's messianic e without completely dis5 of the Sian Sawng secesbliterate its existence. The ristianity in the country ber of congregations, and hould remember that the itry in 1899 (Maung Shwe tholic presence, well eviinly really intensified and 2003).

'hristianity in 1937 when before becoming Catholic riving me from one stele $r$ old home. It was a true : had invited me, and an :ft a few discreet tears in $h$ high-born by birthrow leans on steep slope $s$ of the same type. It is pery path and nothing in n other houses. The conld and large family home $v$. One can see the vast ade and made of heavy, ouse itself and its depen-

g space was the preserve s depicted almost exactly g (Figure 31). The stone ra where a mithan (Bibos sacrificial post, trying to takes place where there Man Za Go, with the flag tall pole. The engraving members dancing and he perimeter: again, the

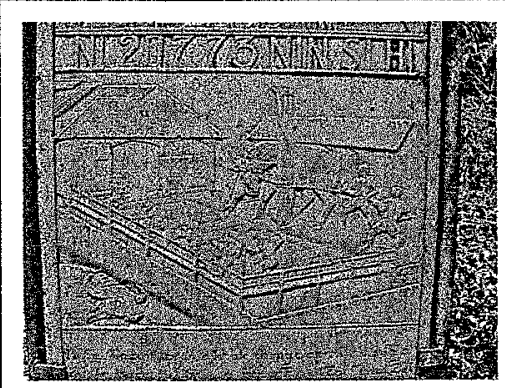

Figure 31 Tualzang(Tedim): sacrifice depicted on the esplanade of a house.

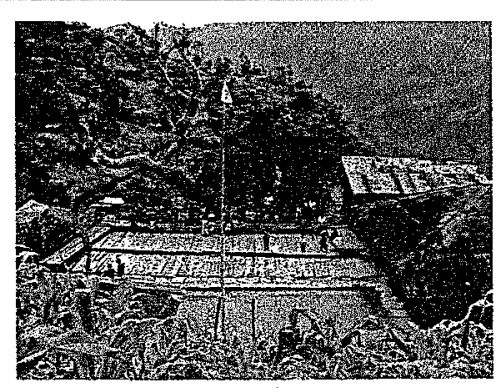

Figure 32 Saizang: Jehovah's Witness school and the former home of Man Za Go.

same place where presently students from the denominational school quietly take their places before they are allowed to enter the former private esplanade which is now a playground. One can also see on those engravings the four-sloped roof of a house as well as an adjacent gable-roofed building which-modernized-still exists today with only the construction materials changed: shingles have now been replaced by corrugated iron. From one generation to the next, the masters of the house have transformed themselves from being clan leaders to denominational schoolteachers. Segmental dynamics, therefore, are still operational; with the clan dimension being taken over by the religious dimension, without its essence having been radically altered.

The steles have not escaped the onslaught of Christianity. In the village of Saizang, a towering white cross faces a group of standing stones (Figure 33). This cross was placed there in 1980, at the initiative of the brother of Mang Za Go, a resident of Yangon for several decades. Nonetheless, it is not technically speaking, an "exorcism." While the standing stones do refer to a defunct shamanic past-as well as to forms of political organization and clan solidarity that are long gonethey are not actual tombs for the souls of ancestors or even altars erected to propitiate the wandering spirits. Through their commemorative dimensions, the steles "merely have 


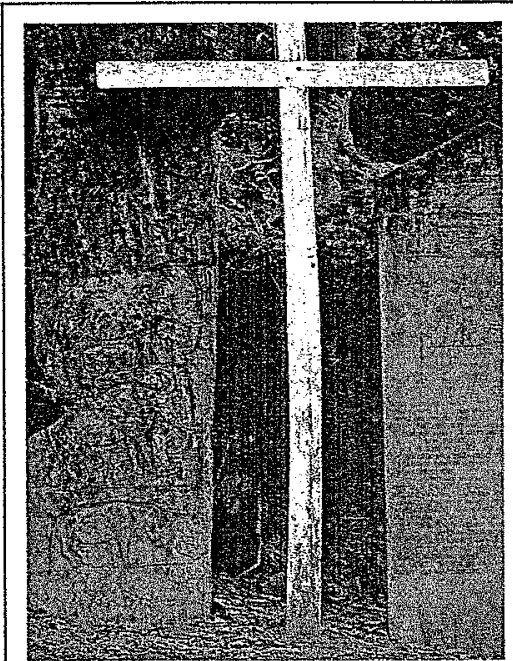

Figure 33 Steles SZ02 and SZ04.

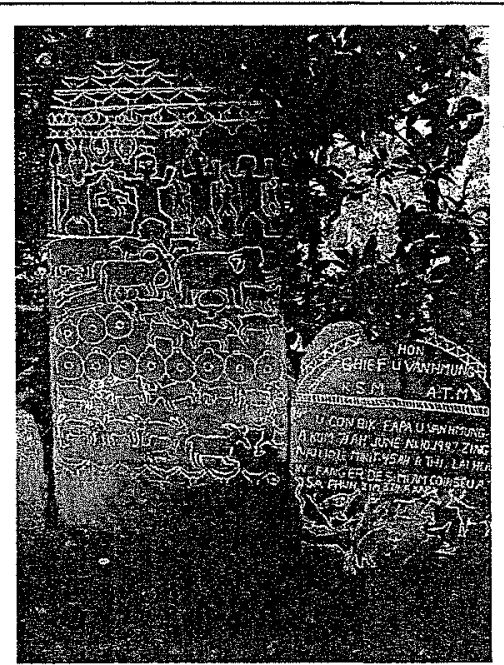

Figure 34 Steles TSH.

the duty" to perpetuate the link between village forerunners and their descendants. Or, nowadays, between a beloved family member who died away from the homeland, and his family members - which allows for Christian principles to be accommodated. In this sense, the installation of this cross can be understood as an act of appropriation of the memorial space by Christianity without jeopardizing the rootedness to the land which the standing stones represent.

With, if not the disappearance of the clan referent, at least his subjection to religious allegiances, it is the true unraveling of the concept of ancestrality, which becomes apparent with the steles. Following the tutelage of the country to the Burmese junta since the 1962 coup, village leaders have lost all their powers, except the responsibility to account to the Burmese authorities, reflective of every possible pressure that may be put upon them under a dictatorial regime. The pressure is so potent that it is ordinarily difficult to find amongst the villagers volunteers who want to take on the function of chief. Markedly, those who now do take on that position are often figures who already served in governmental administration.

Whether they had beer pendence fighters, the clan in local dialects, benefited $\mathrm{f}$ imacy conferred on them Burmese-originated term, resentative to the central $\mathrm{g}$ the yayaka cannot make any of any clan legitimacy, he power.

Religious authorities at nized as the most respecte. their influence actually . simply being "moral authc of creating a trend towar Christian proselytism and as well as a tendency by th priate lands and other ric (Danel-Fédou and Robinn

\section{In Memoriam}

If there is a constant whic wars and proselytism, it is tion dynamics and on its 1 rooting in an ancestral $h$ expanding and growing compels men to depart ev can range from a few wet tion growth that leads entj very faraway urban centes religious incentive that $\mathrm{pr}$ Christian universities in guarantees that at least on to make the choice to go least the political pressu: those in New Delhi, claim

It is often a combinatio] triation: with those leavin 
Whether they had been heroes of the resistance or independence fighters, the clan leaders, called bawi, hausa, or $u k p i$ in local dialects, benefited from the symbolic power and legitimacy conferred on them by ancestrality. In contrast, the Burmese-originated term, yayaka, designates the village representative to the central government. Devoid of any budget, the yayaka cannot make any collective investment; and devoid of any clan legitimacy, he also no longer has any symbolic power.

Religious authorities are now, de facto, becoming recognized as the most respected public figures in the region; with their influence actually extending much further beyond simply being "moral authorities." This has had the dual effect of creating a trend toward community dispersion-due to Christian proselytism and to strong conversion dynamicsas well as a tendency by the religious hierarchy to self-appropriate lands and other riches: often through a "God's tax" (Danel-Fédou and Robinne 2007).

stween village forerunners days, between a beloved om the homeland, and his : Christian principles to be istallation of this cross can 'priation of the memorial ardizing the rootedness to ; represent.

$f$ the clan referent, at least is, it is the true unraveling h becomes apparent with he country to the Burmese eaders have lost all their ) account to the Burmese ible pressure that may be egime. The pressure is so $\supset$ find amongst the villagon the function of chief. on that position are often rnmental administration.

\section{In Memoriam}

If there is a constant which appears throughout a century of wars and proselytism, it is that the focus should be on migration dynamics and on its byproduct, the continued symbolic rooting in an ancestral homeland. Presently, everything is expanding and growing: the economic situation which compels men to depart every year for Manipur for stays that can range from a few weeks to several months; the population growth that leads entire families to sometimes resettle in very faraway urban centers like Rangoon and Mandalay; the religious incentive that pushes youths to leave for study in Christian universities in India; and family pressure which guarantees that at least one child in a nuclear family will have to make the choice to go to Malaysia to find a job. And not least the political pressure, which many refugees such as those in New Delhi, claim caused their flight.

It is often a combination of all these that causes such expatriation: with those leaving benefiting from very diverse net- 
works, including clan connections, even though the shapes of communitarianism have been long evolving. The departure of clan members, whether for shorter or longer periods, along more or less regular routes with destinations faraway or not, displays clearly the structural arrangements of villages in Chin State. Yet at the same time, by comparison, these members' return remains seemingly uncertain and unpredictable. However, during the interviews, it became clear that: (1) the link to the homeland remains unwavering; and (2) this territorial link exists through the concept of ancestrality and other commemorative memory exercises.

Those who chose to expatriate themselves by moving to the city are thereby settling within an entirely Burmese milieu: dominated by the idea that "being Burmese is being Buddhist." For them, visits back to their homeland allow them to keep in touch with those who chose to stay behind: typically the wives and womenfolk, the youths, and the elders. As such, the purpose of these visits is at once to introduce parents to the next generation, to pay tribute to elders, and to simultaneously commemorate the founding ancestors. This is how the steles become painted in blue, using the same thick paint that is utilized in Rangoon and Mandalay to restore - at the end of car races-some semblance of shine to the small cars nicknamed "four-wheels." In the same way, the lines in the engravings are covered in white paint to better bring out their patterns (Figure 34); and Christian crosses are sometimes erected in front of those commemorative stones (Figure 33).

Christian commemoration, however, takes other forms beyond the re-appropriation of standing stones. In taking over the cultural markers which are the steles, Christians have also transformed their styles: the imposing standing stones of the past-pictorially engraved and without any writing - have been succeeded by small brick constructions with painted texts and motifs. Moreover, it is the influence of Christians that popularized the concept of individualized commemorative steles. By making the steles' commemorative purposes its own, Christianity has hastened the metamor-

phosis of the stones, whil principal commemorativı

I would like to thank Murielle Morı Lai Uk Nawl, known as Ukte, whc optimal conditions, despite the $d$ wonderful logistics put at our dis] in the districts of Hakha, Falam, an Sawn Thanget Hau Sian Kham of Nang, and Mang Za Ngin of Mualk me to detail and better understanc am particularly indebted to Profes and the anonymous reviewers of $t$

François Robinne received his $\mathrm{Pr}$ études en sciences socials (EHESS Centre national de la recherche sci tute on Contemporary Southeast . research experience in ethnic and the concept of "transethnicity." Hi tions interethniques dans l'Etat Shan chamanes. Métamorphoses kachin (L Dynamics in the Highlands of Southe Burma by E.R. Leach (Brill, 2007 w Considering the Other through Ethno with C. Culas). He is currently wor tentatively entitled Myanmar in Tra and NUS Press, forthcoming). He

\section{Bibliography}

Barbier, Jean-Paul et al. 199؛ de l'Tndonésie primitiv Mualler. Geneva: Coé

Bareigts, André. 1980. La m Fengpin. 1981. Les Lautu. Cont d'une ethnie chin de $\mathrm{Hl}$ 2003. The Beginning of the Chin Hills. Taiwan

Bouchery, Pascal. 1995. "I population tibéto-bir Chine." PhD diss., U1

Carey, Bertram S. and Tus History of the People, $\mathrm{O}$ 
;, even though the shapes long evolving. The deparshorter or longer periods, with destinations faraway ural arrangements of viltime, by comparison, these gly uncertain and unpreterviews, it became clear remains unwavering; and ih the concept of ancestralnory exercises.

themselves by moving to n entirely Burmese milieu: $\mathrm{g}$ Burmese is being Budeir homeland allow them hose to stay behind: typire youths, and the elders. its is at once to introduce pay tribute to elders, and the founding ancestors. ed in blue, using the same ngoon and Mandalay to ime semblance of shine to heels." In the same way, :ed in white paint to better and Christian crosses are ie commemorative stones

vever, takes other forms anding stones. In taking are the steles, Christians ;: the imposing standing graved and without any small brick constructions :over, it is the influence of oncept of individualized he steles' commemorative ; hastened the metamor- phosis of the stones, while at the same time kept them as the principal commemorative vehicle for the people.

I would like to thank Murielle Morrison and all members of the local team, especially Lai Uk Nawl, known as Ukte, who made sure this study could be conducted under optimal conditions, despite the difficulties inherent to the Burmese context. The wonderful logistics put at our disposal enabled us to survey more than 30 villages in the districts of Hakha, Falam, and Tedim. My deepest gratitude also goes to Dong Sawn Thanget Hau Sian Kham of Tedim, Lian Cin Dal, Lian Kho Nang, Hau Khan Nang, and Mang Za Ngin of Mualbem, as well as Man Za Go of Saizang who helped me to detail and better understand the genealogies I had collected onsite. Finally, I am particularly indebted to Professor F.K. Lehman (U Chit Hlaing), Fanny Potkin, and the anonymous reviewers of this article for their valuable comments.

François RoBINNE received his PhD in social anthropology from École des hautes études en sciences socials (EHESS) in 1985 and is presently Director of Research at Centre national de la recherche scientifique (CNRS) and head of the Research Institute on Contemporary Southeast Asia (IRASEC) in Bangkok. With many years of research experience in ethnic and religious identities in Burma, he also developed the concept of "transethnicity." His publications include: Fils et maittres du Lac. Relations interethniques dans l'Etat Shan de Birmanie (CNRS Editions, 2000) and Prêtres et chamanes. Métamorphoses kachin (L'Harmattan, 2007). He is also co-editor of Social Dynanics in the Highlands of Southeast Asia: Reconsidering Political Systems of Highland Burma by E.R. Leach (Brill, 2007 with M. Sadan) and Inter-Ethnic Dynamics in Asia: Considering the Other through Ethnonyms, Territories and Rituals (Routledge, 2009; 2013 with C. Culas). He is currently working on, with Renaud Egreteau, an edited volume tentatively entitled Myanmar in Transition: Social and Political Metamorphosis (IRASEC and NUS Press, forthcoming). He can be reached at francois.robinne@irasec.com.

\section{Bibliography}

Barbier, Jean-Paul et al. 1999. Messages de pierre-Statues et sculptures de l'Indonésie primitive dans les collections du musée BarbierMualler. Geneva: Coédition Skira/Ed du Seuil.

Bareigts, André. 1980. La maison Lautu et les fêtes de mérite. Taiwan: Fengpin. . 1981. Les Lautu. Contribution à l'étude de l'organisation sociale d'une ethnie chin de Haute Birmanie. Paris: SELAF. . 2003. The Beginning of the Catholic Church in the Central Part of the Chin Hills. Taiwan: Fengpin.

Bouchery, Pascal. 1995. “Les Hani: introduction à l'étude d'une population tibéto-birmane du Yunnan en relation avec la Chine." PhD diss., Université de Paris X-Nanterre.

Carey, Bertram S. and Tuck, H.N. 1976 [1896]. The Chin Hills: $A$ History of the People, Our Dealings with Them, Their Customs and 
Manners, and a Gazetter of Their Country. Aizawl (Mizoram): Tribal Research Institute, Firma KLM Provate Ltd., 2 vols.

Colani, Madeleine. 1935. Mégalithes du Haut-Laos (Hua Pan, Tran Ninh). Paris: Publications de l'EFEO, vol. XXV-XXVI.

Crosthwaite, Sir Charles. 1912. The Pacification of Burma. London: Frank Cas and Co.

Danel-Fédou, Grégoire and François Robinne. 2007. Microcrédit et changement social au Myanmar (Birmanie). Une étude anthropologique et économique dans l'Etat Chin. Paris: Les Editions du GRET, Collection "Etudes et Travaux."

Graeber, David. 1997. "Painful Memories." Journal of Religion in Africa 27(4): Religion in Madagascar II: 374-400.

Head, W.R. [1917] 1955. Hand Book of the Haka Chin Customs. Rangoon: Union Govt. Printing and Staty.

Heine-Geldern, R. 1959. "Das Megalithproblem." 1958 Symposion der Wenner-Gren Foundation. Horn, Austria.

Hutton, John Henry. [1921] 1969. The Angami Nagas: With Some Notes on Neighbouring Tribes. Oxford: Oxford University Press. 1922. "The Meaning and Method of the Erection of Monololiths by the Naga Tribes." Journal of the Royal Anthropological Institute 52: 242-9.

Lalthanglia, B. 1975. History of Mizo in Burma. Aizawl: Zawlbuk Agencies.

Lehman, F.K. 1963. The Structure of Chin Society: A Tribal People Adapted to a Non-Western Civilization. Illinois Studies in Anthropology No. 3. Urbana, IL: The University of Illinois Press.

Lévi-Strauss, Claude. [1962] 2008. La pensée sauvage. Paris: Gallimard, Bibliothèque de La Pléiade.

Maung Shwe Wa. 1963. Burma Baptist Chronicle, Book 1; Baptist Chronicle, Book 2, ed. G. Sowards and E. Sowards. Rangoon: Board of Publications, Burma Baptist Convention.

McCall, Anthony Gilchrist. 1949. Lushai Chrysalis. London: Luzac and $\mathrm{Co}$.

Otto, Ton and Nils Bubandt, eds. 2010. Experiments in Holism: Theory and Practice in Contemporary Anthropology. Chichester: John Wiley and Sons.

Pandey, Anshuman. 2011. "Proposal to Encode the Pau Cin Hau Alphabet in ISO/IEC 10646." http://std.dkuug.dk/jtc1/sc2/ wg2/docs/n4017.pdf.

Parry, N.E. 1932. The Lakhers. With an introduction and supplementary notes by Dr. J.H. Hutton. London: Macmillan and Co.
Postel, Michel and Cooper, Figurines and Memorial: Studies, Publication V]

Ramirez, Philippe. People of $\mathrm{i}$ North-East India. Guwa

Rousseleau, Raphaël. 2008. discours britanniques 97-111.

Rousseleau, Raphaël. (Forthc scapes and Cultures: Present Ethnograhic Ir

Roy, Olivier. 2008. La sainte culture. Paris: Seuil, co

Sakhong, Lian H. 2003. In Se Politics and Ethnic Ident

Scott, James A. 2009. The A History of Upland South University Press.

Settar, S. and Gunther D. So Study of Their Origin Instititute of Indian A Asia Institute.

Stevenson, H.N.C. [1943] 1 Tribes. Bombay: The T

van Schendel, Willem. 200: phies of Ignorance: Jv ronment and Planning i

von Fürer-Haimendorf, $\mathrm{Ch}$ lithic Cultures in Mid.

Ziegler, Arlette and Alain Statuaire et mégalithi Statues et sculptures de du musée Barbier-Mua Seuil, 35-78. 
Country. Aizawl (Mizoram): KLM Provate Ltd., 2 vols. lu Haut-Laos (Hua Pan, Tran FEO, vol. XXV-XXVI.

'acification of Burma. London:

Robinne. 2007. Microcrédit et (Birmanie). Une étude anthro$t$ Chin. Paris: Les Editions du ivaux."

tories." Journal of Religion in ar II: 374-400.

: of the Haka Chin Customs. and Staty.

:thproblem." 1958 Symposion m, Austria.

ngami Nagas: With Some Notes Jxford University Press.

$\mathrm{d}$ of the Erection of Monoloal of the Royal Anthropological

in Burma. Aizawl: Zawlbuk

Chin Society: A Tribal People on. Illinois Studies in Anthroniversity of Illinois Press. pensée sauvage. Paris: Gallie.

ist Chronicle, Book 1; Baptist $s$ and E. Sowards. Rangoon: ptist Convention.

ıai Chrysalis. London: Luzac

Experiments in Holism: Theory thropology. Chichester: John

to Encode the Pau Cin Hau http://std.dkuug.dk/jtc1/sc2/

atroduction and supplemenndon: Macmillan and Co.
Postel, Michel and Cooper, Zarine. 1999. Bastar Folk Art: Shrines, Figurines and Memorials. Mumbai: Project for Indian Cultural Studies, Publication VIII.

Ramirez, Philippe. People of the Margins: Across Ethnic Boundaries in North-East India. Guwahati: Spectrum, 2014.

Rousseleau, Raphaël. 2008. "Les tribus 'mégalithiques' dans les discours britanniques sur l'Inde (1740-1945)." Gradhiva 8: 97-111.

Rousseleau, Raphaël.(Forthcoming). “North-East'Megalithic' Landscapes and Cultures: From British Romantic Discourses to Present Ethnograhic Interpretations."

Roy, Olivier. 2008. La sainte ignorance. Le temps de la religion sans culture. Paris: Seuil, collection "La couleur des idées."

Sakhong, Lian H. 2003. In Search of Chin Identity: A Study in Religion, Politics and Ethnic Identity in Burma. Copenhagen: NIAS Press.

Scott, James A. 2009. The Art of Not Being Governed: An Anarchist History of Upland Southeast Asia. New Haven and London: Yale University Press.

Settar, S. and Gunther D. Sontheimer, eds. 1982. Memorial Stones: A Study of Their Origin, Significance and Variety. Dharward: Instititute of Indian Art and History and Heidelberg, South Asia Institute.

Stevenson, H.N.C. [1943] 1968. The Economics of the Central Chin Tribes. Bombay: The Times of India Press.

van Schendel, Willem. 2002. "Geographies of Knowing, Geographies of Ignorance: Jumping Scale in Southeast Asia." Environment and Planning D: Society and Space 20: 647-68.

von Fürer-Haimendorf, Christoph. 1945. "The Problem of Megalithic Cultures in Middle India." Man in India 25(2): 73-86.

Ziegler, Arlette and Alain Viaro. 1999. "Les pierres du pouvoir. Statuaire et mégalithisme de Nias." In Messages de pierreStatues et sculptures de l'Indonésie primitive dans les collections du musée Barbier-Mualler, ed. Jean-Paul Barbier. Paris: SkiraSeuil, 35-78. 